\title{
Aluminum electrocoagulation as pretreatment during microfiltration of surface water containing NOM: A review of fouling, NOM, DBP, and virus control
}

Shankararaman Chellam ${ }^{*}$ and Mutiara Ayu Sari

Zachry Department of Civil Engineering, Texas A\&M University, College Station, TX 77843-3136

\section{ABSTRACT}

Electrocoagulation (EC) is the intentional corrosion of sacrificial anodes (typically aluminum or iron) by passing electricity to release metal-ion coagulant species and destabilize a wide range of suspended, dissolved, and macromolecular contaminants. It can be integrated ahead of microfiltration (MF) to effectively control turbidity, microorganisms, and disinfection by-products (DBPs) and simultaneously maintain a high MF specific flux. This manuscript summarizes the current knowledge on MF pretreatment by aluminum EC particularly focusing on mechanisms of (i) electrocoagulant dosing, (ii) (bio)colloid destabilization, (iii) fouling reductions, and (iv) enhanced removal of viruses, natural organic matter (NOM), and DBP precursors. Electrolysis efficiently removes hydrophobic NOM, viruses, and siliceous foulants. Aluminum effectively electrocoagulates viruses by physically encapsulating them in flocs, neutralizing their surface charge and reducing electrostatic repulsion, and increasing hydrophobic interactions between any sorbed NOM and free viruses. New results included herein demonstrate that EC achieves DBP control by removing NOM, reducing chlorine-reactivity of remaining NOM, and inducing a slight shift towards more brominated trihalomethanes and haloacetic acids. EC reduces MF fouling by forming large flocs that tend to deposit on the membrane surface, i.e. decrease pore penetration and forming more permeable cakes and by reducing foulant mass in case of significant floc-flotation.

Keywords. Electrocoagulation, Microfiltration, Drinking water treatment, DBPs, Pretreatment

* J. Walter "Deak" Porter '22 \& James W. “Bud" Porter '51 Professor and corresponding author, Phone: (979) 458-5914, Fax: (979) 862-1542, email: chellam@tamu.edu 


\section{BACKGROUND AND INTRODUCTION}

The United Nations estimates that 1.2 billion people currently live in areas of physical water scarcity, a number which is projected to increase to 1.8 billion by the year 2025 [1]. The deteriorating quality of existing "freshwater" sources, uncertainties in precipitation associated with climate change, and unsustainable water usage, necessitate advanced treatment technologies to quench the thirst of a growing population. It is prudent to meet the growing demand using surface water since excessive groundwater extraction causes land subsidence damaging the builtinfrastructure and wetlands and increasing the frequency and intensity of flooding [2]. However, surface water purification requires advanced water treatment technologies since it is typically laden with high concentrations of particles (i.e. turbidity), pathogenic microorganisms, and precursors to potentially carcinogenic, teratogenic, and mutagenic disinfection by-products (DBPs), i.e. natural organic matter (NOM) [3].

Microfiltration (MF) and ultrafiltration (UF) are low-pressure liquid-solid membrane separation technologies that have found widespread use in purifying drinking water and wastewater largely because they directly remove Giardia, Cryptosporidium, bacteria, and turbidity [4]. Physical removal of difficult-to-inactivate parasites significantly reduces the requisite chemical disinfectant concentrations to meet primary microbiological drinking water standards when MF and UF are implemented for water treatment. In turn, lower disinfectant concentrations decrease DBP formation. Hence, MF and UF directly reduce microbial risks and indirectly reduce chemical risks in the water we drink. However, waterborne viruses [5-7] and natural organic matter (NOM) largely pass unimpeded across MF and UF membranes [8-10]. Importantly, micro- and ultrafilters are subject to fouling, which refers to reducing permeate flux (at constant pressure) or increasing transmembrane pressure (at constant flux) [4]. Fouling decreases productivity, which can be partially counteracted by pretreating the feed water thereby facilitating MF and UF implementation.

One common membrane pretreatment method is coagulation where traditionally aluminum or iron salts are added externally to the feed water ahead of MF or UF $[7,11-13]$. Recent advances in electrochemical technologies have generated much interest in evaluating them as alternatives to conventional coagulants [14, 15]. During electrocoagulation (EC), current is passed through a sacrificial anode to dissolve coagulant precursor ions in situ, which hydrolyze rapidly to form dissolved hydroxyl complexes and insoluble hydroxide precipitates. Gas exsolution during electrolysis sometimes leads to floc-flotation, which is sometimes termed electroflotation (EF) when the floating layer is skimmed and only the remaining non-floating colloids present in the water column are sent 
downstream for additional liquid-solid separation [16-18]. The burgeoning interest in applying electrolytic technologies can be attributed to their (i) suitability for use in predesigned portable packaged plants, (ii) reduced use of corrosive chemicals, (iii) availability of optimized module configurations, and (iv) effectiveness over a wide range of water chemistries (e.g. varying $\mathrm{pH}$ and alkalinity) $[19,20]$. Most previous investigations and reviews of EC have focused on its capabilities as a stand-alone process to remove physicochemical contaminants including arsenic, copper, zinc, fluoride, turbidity, NOM, etc. [21-31]. However, electrochemical processes are beginning to be integrated with low-pressure membranes e.g. $[16,32-40]$ necessitating their optimization in close conjunction with MF/UF, which is our focus. The principal objectives of this work are to summarize the state-of-the-art of integrated electrochemical and MF/UF systems for drinking water treatment emphasizing (i) aluminum electrodissolution reactions, (ii) membrane fouling mechanisms, and (iii) control of NOM, DBP precursors, and viruses. Only limited information on iron EC is presented herein and the reader is referred elsewhere for detailed information about this process $[15,20,38,41,42]$. It is emphasized that we focus largely on results generated in our laboratories and NOM and DBP precursor control results presented herein are previously unpublished information.

\section{EXPERIMENTS}

The majority of data that this review is based on was obtained from our earlier publications [16, 38-40, 43-46]. However, new experiments were also performed to generate data on DBP control since this topic is central to surface water treatment and as yet, such information is not available in the literature for integrated EC/MF. Membrane fouling control and removal of viruses, NOM, and DBP precursors was studied using Lake Houston as a representative surface water whose important characteristics are summarized in Table 1. As seen, this lake can be characterized as being moderately turbid, low in dissolved salts, hardness, and buffering capacity, and moderately high in NOM content.

Table 1. Summary of Lake Houston water quality parameters

\begin{tabular}{|c|c|c|}
\hline Parameter & Unit & Concentration or value \\
\hline $\mathrm{pH}$ & - & $7.9 \pm 0.16$ \\
\hline Turbidity & $\mathrm{NTU}$ & $18.8 \pm 1.0$ \\
\hline Dissolved organic carbon & $\mathrm{mg} / \mathrm{L}$ & $6.9 \pm 0.3$ \\
\hline $\mathrm{UV}_{254}$ & $\mathrm{~cm}^{-1}$ & $0.170 \pm 0.009$ \\
\hline Conductivity & $\mu \mathrm{S} / \mathrm{cm}$ & $394.4 \pm 14.9$ \\
\hline Chloride & $\mathrm{mg} / \mathrm{L}$ & $22.1 \pm 3.2$ \\
\hline Total hardness & $\mathrm{mg} / \mathrm{L} \mathrm{as} \mathrm{CaCO}$ & $67 \pm 3.3$ \\
\hline
\end{tabular}




\begin{tabular}{|c|c|c|} 
Calcium hardness & $\mathrm{mg} / \mathrm{Las} \mathrm{CaCO}_{3}$ & $56.1 \pm 2.1$ \\
\hline Alkalinity & $\mathrm{mg} / \mathrm{Las} \mathrm{CaCO}_{3}$ & $85.7 \pm 3.2$ \\
\hline Dissolved silica & $\mathrm{mg} / \mathrm{L}$ as $\mathrm{SiO}_{2}$ & $9.36 \pm 3.84$ \\
\hline
\end{tabular}

Dissolved organic carbon (DOC) was measured using the combustion infrared method (Shimadzu 5050TOC, Columbia, $\mathrm{MD}$ ) after acidification and $\mathrm{N}_{2}$ purging. Ultraviolet absorbance at $254 \mathrm{~nm}$ was measured using a $\mathrm{DR} / 4000$ spectrometer (Hach Company, Loveland, $\mathrm{CO}$ ) with a 1-cm path length quartz cell. Water samples were prefiltered using a $0.45 \mu \mathrm{m}$ syringe filter to avoid interferences from suspended particles for both DOC and UV 254 . DBP precursor removal was measured at simulated distribution system (SDS) conditions ( 24 hour contact time, $20^{\circ} \mathrm{C}$ temperature, $\mathrm{pH} 8.3$, and $1 \mathrm{mg} / \mathrm{L}$ free $\mathrm{Cl}_{2}$ residual). Water samples were first collected in demand free amber colored bottles, buffered with borate, and dosed with the appropriate amount of chlorine solution to have a residual of $1 \pm 0.2 \mathrm{mg} / \mathrm{L}$ after 24 hours. Four THMs $\left(\mathrm{CHCl}_{3}, \mathrm{CHCl}_{2} \mathrm{Br}, \mathrm{CHClBr}_{2}, \mathrm{CHBr}_{3}\right)$ were analyzed by EPA Method 551.1; i.e. liquid/liquid extraction with tertiary-butyl methyl ether and by gas chromatography with electron capture detection. Six haloacetic acids containing chlorine and bromine (monochloroacetic acid, dichloroacetic acid, trichloroacetic acid, monobromoacetic acid, dibromoacetic acid, and bromochloroacetic acid) were analyzed by EPA Method 552.2 (i.e. liquid/liquid extraction, derivatization with acidic methanol, and gas chromatography with electron capture detection.

Electrocoagulation was conducted at pH 6.3 (near the pH of minimum Al solubility) and a current density of 20 $\mathrm{mA} / \mathrm{cm}^{2}$ that necessitated a voltage of nearly $10 \mathrm{~V}$. The anode was a Puratronic grade aluminum (99.9965\% as Al, Alfa Aesar) rod fitted inside a perforated hollow 316-stainless steel cathode with $2 \mathrm{~mm}$ spacing constituting an annular geometry. The anode was mechanically scrubbed and gently washed with weak acid to present a polished surface for each experiment. Total aluminum was measured by atomic absorption spectroscopy (Flame AA-AAnalyst 300, PerkinElmer) after acidifying samples to $<2$ using $\mathrm{HCl}$ according to Standard Method 3111. More details on the source water and the electrocoagulation apparatus can be obtained from our previous publications [16, 38-40, 43-46]. After select EC experiments, flocs were harvested, vacuum dried, and examined using powder X-ray photoelectron spectroscopy (XPS). Both survey scans (0-1400 eV) and high-resolution spectra were obtained for photoelectrons with a $1.1 \mathrm{~mm}$ spot diameter.

Unstirred MF was performed at constant pressure (2-24 psig) using a $4.1 \mathrm{~cm}^{2}$ disc PVDF membrane with pores 
rated at $0.22 \mu \mathrm{m}$. First, $100 \mathrm{~mL}$ of ultrapure water was passed through the system first to measure the clean membrane resistance. Then, a minimum of $150 \mathrm{~mL}$ of the electrocoagulated suspension was filtered during which time the instantaneous pressure and cumulative filtered water volume were monitored at a variable frequency between $0.1-1 \mathrm{~Hz}$ using a computerized data acquisition system and a program written in LabVIEW $[16,39,40,47$, 48]. To probe fouling mechanisms, the instantaneous flux $\frac{d\left(V / A_{m}\right)}{d t}$ was first obtained by numerically differentiating the cumulative volume filtered $(V)$ per unit membrane area $\left(A_{m}\right)$ after exponential smoothing and analyzing it using blocking laws [47-49]:

$$
\begin{array}{ll}
\frac{d t}{d\left(V / A_{m}\right)}=\frac{1}{J_{o}} e^{k_{i}\left(V / A_{m}\right)} & \text { (intermediate blocking) } \\
\frac{d t}{d\left(V / A_{m}\right)}=k_{c}\left(\frac{V}{A_{m}}\right)+\frac{1}{J_{o}} & \text { (cake filtration) }
\end{array}
$$

where $\mathrm{J}_{\mathrm{o}}$ is the initial permeate flux and $\mathrm{k}_{\mathrm{i}}$ and $\mathrm{k}_{\mathrm{c}}$ are parameters describing intermediate blocking and cake filtration respectively [4].

\section{COAGULANT ELECTRODISSOLUTION}

We have reported short-term coagulant electrodissolution into Lake Houston to quantitatively obey Faraday's law (Equation 3), where $\mathrm{m}$ is the total mass of iron or aluminum (g), AW is the atomic weight of the elemental coagulant precursor (i.e. $55.85 \mathrm{~g} / \mathrm{mol}$ for Fe and $26.98 \mathrm{~g} / \mathrm{mol}$ for $\mathrm{Al}$ ), $\mathrm{I}$ is the electric current $(\mathrm{A}), \mathrm{t}$ is time $(\mathrm{s}), \mathrm{z}$ is number of electrons transferred, and $\mathrm{F}$ is the Faraday's constant $(96,486 \mathrm{C} / \mathrm{eq})[16,38,39,44]$.

$$
\mathrm{m}=\frac{\mathrm{AWIt}}{\mathrm{zF}}
$$

Applying Equation 3 to laboratory measurements during surface water EC has provided evidence for a 3- and 2electron transfer for aluminum and iron EC respectively [16, 38, 39, 44]. Electrodissolved coagulant concentrations increased linearly with the amount of electrical charge passed as predicted by Faraday's law. Hence, chemical dissolution, which has been reported to augment electrocoagulant dosing to super-Faradaic levels at high chloride ion concentrations $[17,45,50]$ does not appear to be significant under our experimental conditions for low salinity surface water. Accurate Faraday's law predictions also arise from vigorously cleaning the anode prior to each experiment $[41,50,51]$. Additionally, since Lake Houston water is NOM-laden and low in salinity and chloride ion 
concentration, chemical dissolution, pitting corrosion, and chlorine generation did not accompany electrolysis [17, 50]. Hence, all electrons appear to have participated in anodic aluminum dissolution and similar to another recent report [51], oxygen was not released. Since this behavior can potentially change in the presence of other electrochemically active species and at higher applied voltages, electrocoagulant dosing needs to be evaluated on a case-by-case basis.

These results suggest the following electrochemical reactions for low-salinity, high NOM content surface waters at typical $\mathrm{pH}$ values $[14,15,20,41,52-54]$ :

Anode $\quad \mathrm{Fe}(0)_{(\mathrm{s})} \rightarrow \mathrm{Fe}(\mathrm{II})+2 \mathrm{e}^{-} \quad$ or $\quad \mathrm{Al}(0)_{(\mathrm{s})} \rightarrow \mathrm{Al}(\mathrm{III})+3 \mathrm{e}^{-}$

Cathode $\quad 2 \mathrm{H}_{2} \mathrm{O}+2 \mathrm{e}^{-} \rightarrow \mathrm{H}_{2(\mathrm{~g})}+2 \mathrm{OH}^{-}$

Electrodissolved iron and aluminum undergo hydrolysis to form various mono, di, and polynuclear complexes, which behave as Brønsted acids, consume buffering capacity and tend to reduce pH [28, 55-57]. Hydroxyl ions released at the cathode tend to neutralize the Brønsted acidity of hydrolysis products even causing a temporary upward drift in $\mathrm{pH}$ for typical initial $\mathrm{pH}$ values depending on the buffering capacity of the feed water, current density, and electrolysis duration $[39,50,51]$. Limited change in $\mathrm{pH}$ has been reported for high alkalinity waters or when electrolysis is performed for short-durations [33, 38, 58]. Electrodissolution of highly soluble Fe(II) has been confirmed by direct aqueous phase measurements $[41,44,52]$ and can be problematic since it does not directly induce sweep coagulation. Consequently, Fe(III) is preferred over Fe(II) as a coagulant for water purification applications. However, in the absence of significant NOM concentrations, Fe(II) can be potentially oxidized to precipitate $\mathrm{Fe}(\mathrm{OH})_{3(\mathrm{~s})}$ in oxygenated waters by raising the $\mathrm{pH}$ (kinetics is first order in dissolved oxygen concentration and inverse second order in $\mathrm{pH}$ ) to induce sweep coagulation and enmeshment [21, 59-62]:

$$
4 \mathrm{Fe}(\mathrm{II})+\mathrm{O}_{2}+2 \mathrm{H}_{2} \mathrm{O}+8 \mathrm{OH}^{-} \rightarrow 4 \mathrm{Fe}(\mathrm{OH})_{3(\mathrm{~s})}
$$

Importantly, complexation of electrodissolved Fe(II) inhibits oxidation, limiting the coagulation ability of iron during electrochemical pretreatment if NOM or other chelating agents are present $[38,44,52,63]$. Along with anodic dissolution, hydrogen gas is released from the cathode due to water splitting explaining the observed bubble formation. These bubbles adhere to flocs, which can cause them to float to the top of the water column, which is sometimes referred to as $\operatorname{EF}[16,18,33,60,64-66]$. When the entire electrolyzed suspension is directly filtered (without intermediate liquid-solid separation), the process is referred to as EC $[15,34,35,39,40]$. It is emphasized 
that these definitions, although very useful, are not yet universally accepted in the literature.

A multitude of solid phases have been reported following iron and aluminum EC including predominantly magnetite and maghemite with traces of lepidocrocite and akaganeite in sea water [32], green rust, magnetite, and lepidocrocite in highly colored natural water as well as traces of bayerite and boehmite but predominantly amorphous $\mathrm{Al}(\mathrm{OH})_{3}$ in surface water of moderate NOM content $[16,57,66]$. Raman spectroscopy has provided evidence that operating conditions influence iron polymorphs with dissolved oxygen concentrations being an important parameter [51]. Conditions favoring low dissolved oxygen form green rust, but lepidocrocite is crystallized in oxygen-rich environments, and magnetite is precipitated at intermediate dissolved oxygen values. However, under conditions typical of drinking water treatment, iron oxyhydroxide morphology appears to remain relatively invariant to electrolysis conditions [67]. XPS survey scans of EC flocs from Lake Houston at a $10 \mathrm{mg} / \mathrm{L}$ dosage showed a 1:3 Al:O stoichiometric ratio suggesting formation of insoluble $\mathrm{Al}(\mathrm{OH})_{3(\mathrm{~s})}$ in natural surface water [40]. High resolution spectra of photoelectrons emitted from Al $2 p$ measured the peak location to be $74.55 \mathrm{eV}$ [16] corresponding to the value reported for pure $\mathrm{Al}(\mathrm{OH})_{3}$ [68]. Hence, oxides and oxy-hydroxides formed by EC in natural water appear to be dominated by amorphous $\mathrm{Al}(\mathrm{OH})_{3(\mathrm{~s})}$, separately verified by the lack of crystal habit in electron micrographs [39]. Broad shallow peaks corresponding to boehmite nanocrystals $(\gamma-\mathrm{AlO}(\mathrm{OH}))$ have been observed only in $\mathrm{X}$-ray diffractograms of electrochemically generated solids in buffered nanopure water [39]. In contrast, the weak boehmite signals do not appear in diffractograms following electrolysis of surface water. Hence, NOM disrupts precipitation of crystalline Al precipitates during EC similar to reports for chemical precipitation with $\mathrm{AlCl}_{3}$ [69]. These results demonstrate the strong influence of the source water matrix on the morphology of the in situ precipitated coagulant during EC.

\section{Membrane fouling control by electrochemical pretreatment}

Pretreating seawater by iron EC has been reported to be effective for UF fouling control [32, 33] but not for MF during surface water treatment [38]. This apparent discrepancy could arise from the generated pin-point flocs penetrating the larger pores of the more porous MF polymer matrix compared to the denser UF skin layer or due to the lower NOM content of seawater [32,33]. Iron EC is effective in the absence of NOM [21, 35], but NOM complexes $\mathrm{Fe}(\mathrm{II})[59,63]$, which has been reported to prevent effective sweep coagulation [38, 44]. This is in contrast to conventional iron pre-coagulation, which can efficiently control MF/UF fouling $[38,70,71]$. It is emphasized that 
conventional iron coagulation during water and wastewater treatment is accomplished using Fe(III) salts such as $\mathrm{FeCl}_{3}$ or $\mathrm{Fe}_{2}\left(\mathrm{SO}_{4}\right)_{3}[56]$. Therefore, in situ $\mathrm{Fe}(\mathrm{II})$ oxidation and hydrolysis appears to be significantly less effective than direct hydrolysis of externally added Fe(III) during MF pretreatment of NOM-laden surface water [38].

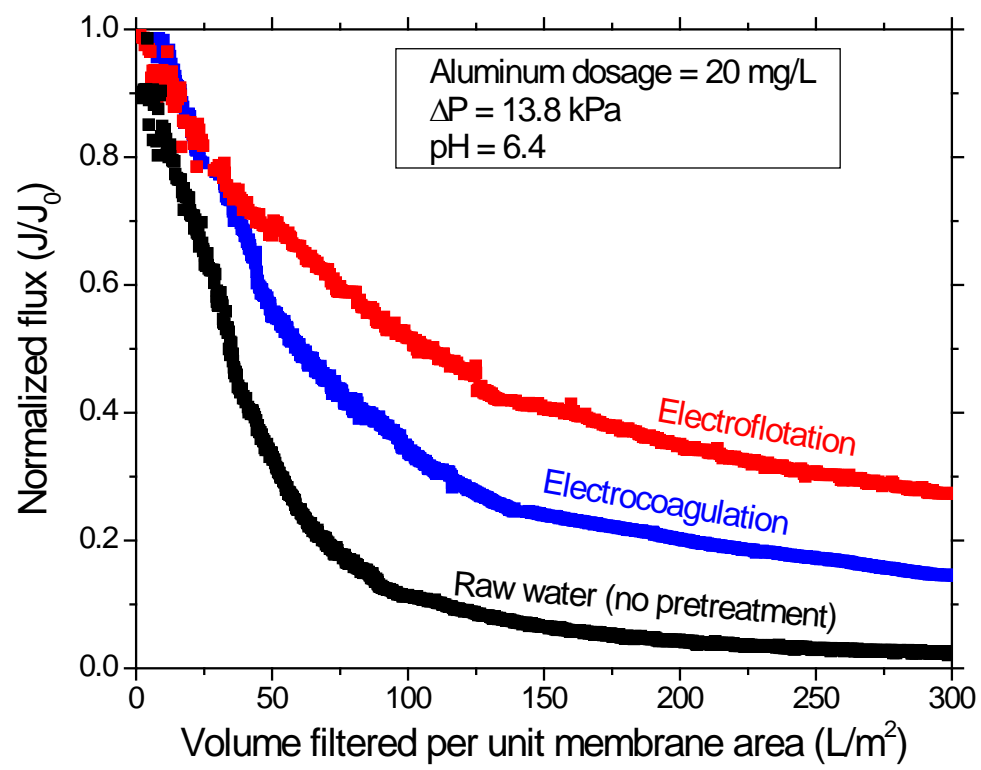

Figure 1. Fouling control during surface water MF by aluminum EC and EF. Note that raw water was obtained from Lake Houston, which contains $\sim 7 \mathrm{mg} / \mathrm{L}$ of NOM measured as dissolved organic carbon (DOC). EF enhances flux over EC primarily by reducing the total mass loading of foulants onto the membrane (data adapted from [16, 39, 40]).

In contrast to iron, aluminum EC has been reported to significantly reduce colloidal fouling during forward MF of NOM-containing surface waters. Figure 1 compares normalized flux during constant pressure dead-end MF for untreated Lake Houston water containing approximately $7 \mathrm{mg} / \mathrm{L} \mathrm{DOC}$ and after electrochemical pretreatment. As seen, the flux decreased severely reaching only $2 \%$ of its initial value in the absence of pretreatment at the conclusion of the experiment. EC pretreatment increased the final flux to $15 \%$ of the initial value and even better results were obtained for EF pretreatment, which enhanced flux to $27 \%$ of the initial value. Aluminum hydrolysis products destabilize foulants by reducing the zeta potential $(\rightarrow 0 \mathrm{mV})$ [39]. Enmeshment into $\mathrm{Al}(\mathrm{OH})_{3(\mathrm{~s})}$ precipitates also forms large flocs reducing penetration into membrane pores and increases cake permeability compared to MF of untreated water $[16,39,40]$. In other words, EC reduces both internal pore fouling and external cake resistance.

Hydrogen bubbles released at the cathode undergo hydrophobic interactions with NOM sorbed on flocs inducing floc-flotation especially over relatively longer electrolysis durations, which can be used to reduce mass loading onto downstream filters by skimming off the floating flocs $[16,17,33,66]$. This explains significantly better MF flux obtained when only the portion of the solids that do not float during electrolysis is microfiltered (i.e. EF over EC pretreatment) as shown in Figure 1. Empirically, floc-flotation has not been reported to be substantial at low 
aluminum dosages $(<\sim 5 \mathrm{mg} / \mathrm{L})$ presumably because bubble number and attachment efficiency is low due to reduced hydrophobic interactions [16]. MF flux is substantially improved when significant flotation occurs during EC, because the solids loading on the membrane i.e. the total foulant mass is reduced. This reduces the cumulative cake resistance of deposited $\mathrm{Al}(\mathrm{OH})_{3}$ flocs even though the specific resistance is higher because smaller particles are preferentially suspended in the water column and sent to the microfilter [16].

Aluminum electrochemical treatment has been shown to best control fouling at (i) pH of lowest solubility (i.e. near 6.3), (ii) an intermediate dosage due to counteracting effects of increasing floc size (that decreases specific resistance) and mass loading (that increases cumulative resistance) as more and more coagulant is added, and (iii) lower transmembrane pressures that compress cakes to a lower extent $[16,34,39]$. Bench-scale testing has revealed an optimum dosage for fouling control to be in the range $10-15 \mathrm{mg} \mathrm{Al} / \mathrm{L}$ for Lake Houston $[16,39,40]$.

4.1. Flux decline mechanisms. During the early stages of MF of untreated surface water, i.e. with no pretreatment, the inverse instantaneous permeate flux typically exhibits a concave-upward profile with respect to cumulative volume quantitatively obeying Equation 1 . This is shown in Figure 2 by the exponential fit to the early portion of the curve (from $0-\sim 200 \mathrm{~L} / \mathrm{m}^{2}$ ) in green color and labeled "intermediate blocking." As filtration of the untreated water progresses and more and more particles are deposited on the surface of the membrane, the inverse instantaneous flux profile transitions to a straight line relationship corresponding to cake filtration as quantitated by Equation 2 . This is shown in Figure 2 by the straight line fit to the latter portion of the curve (from $200-350 \mathrm{~L} / \mathrm{m}^{2}$ ) in blue color and labeled "cake filtration" $[4,38,39]$. These data were generated during MF of Lake Houston water at a relatively low pressure of 2 psig and at an optimal Al dosage of $10 \mathrm{mg} / \mathrm{L}$. 


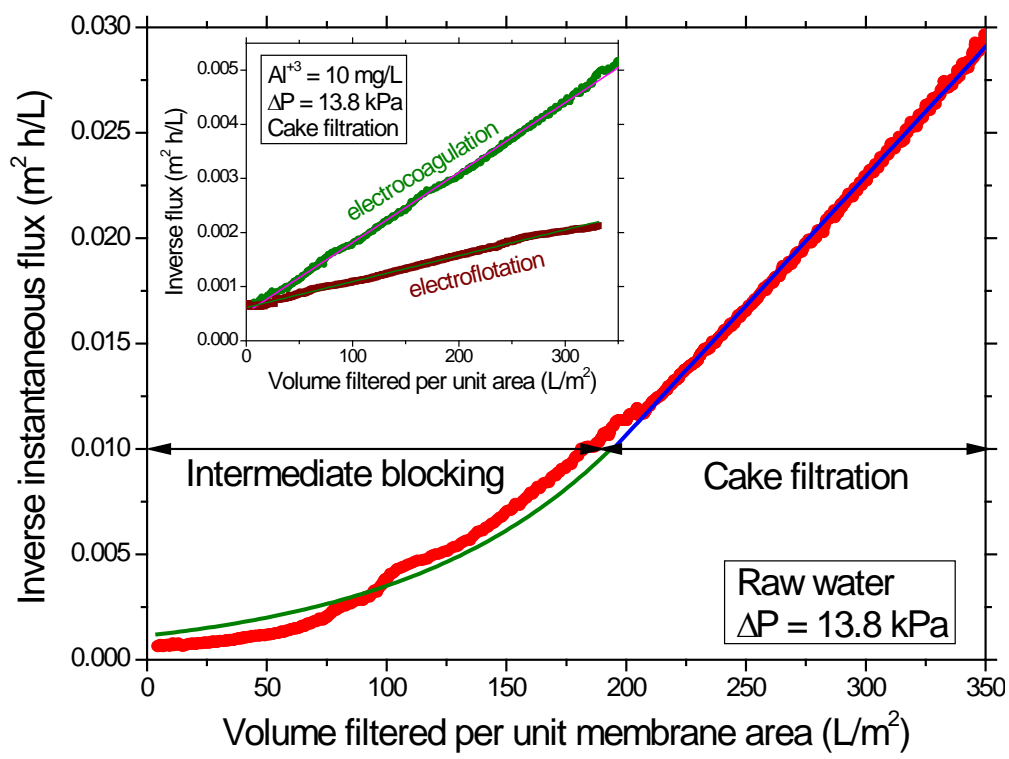

Figure 2. Deducing MF fouling mechanisms from experimental flux profiles. Note a strong concave-upward shape during MF of untreated or raw water, which later transitioned to a straight-line. In contrast, the entire filtration cycle for pretreated waters closely fit a straight-line as shown in the inset (adapted from [16, 38, 39]).

Blocking law modeling suggests that early on, natural colloids have a similar propensity to deposit on previously deposited foulants or on the free microfilter surface to block pores that are open to water permeation as given by the intermediate blocking law (Equation 1). As filtration progresses, viscous resistance to water flow increases as a surficial deposit grows in thickness causing the flux to decline according to cake filtration theory (Equation 2). The initial blocking stage is eclipsed at higher pressures for raw water MF suggesting that the increased rate of foulant deposition at high initial fluxes quickly leads to cake filtration $[48,49]$.

In contrast to raw water, the complete flux profile obeys the cake filtration model for electrochemically pretreated suspensions (entire straight-line behavior in Figure 2 inset). This demonstrates that adding electrocoagulant and increasing the mass concentration of solids in the MF feed water increases the rate of cake layer build-up to a point where a distinct pore blocking phase cannot be observed [16, 38, 39]. An additional concern is that fouling typically worsens with increasing pressure for dead-end MF of electrocoagulated and electrofloated waters due to cake compression:

$$
\alpha^{*}=\alpha_{0}^{*} \Delta P^{n}
$$

where $\alpha^{*}$ and $\alpha_{0}{ }^{*}$ denote the specific resistance at pressure $\Delta \mathrm{P}$ and for an unstressed cake $(\Delta \mathrm{P}=0)$ respectively [39, $72,73]$. It should be noted that the absolute water flux across the membrane increases with pressure according to Darcy's law and the resistance in series approach to modeling MF flux decline [74]. However, MF experiments 
performed in a range of pressures has shown that cake compression decreases the relative flux (instantaneous flux normalized by initial flux) at a faster rate at higher pressures even without any pretreatment [75-77]. When electrocoagulation pretreatment is employed, flocs formed are typically highly open and porous, characterized by low mass fractal dimensions $[16,19,78,79]$. Cake compression is important in EC/MF systems as well in the range 224 psig of transmembrane pressure and aluminum dosages of $2-30 \mathrm{mg} / \mathrm{L}[16,38,39,79]$. These data suggest that inelastic mechanisms such as floc breakage or cake collapse (at the extreme) dominate cake compression [72, 80].

4.2. Chemical aspects of fouling control by electrochemical pretreatment. Recently, there is much interest in utilizing spectroscopic techniques including XPS, Fourier transform infra-red (FTIR), nuclear magnetic resonance (NMR), liquid chromatography, and fluorescence excitation emission matrix to diagnose foulants and MF fouling mechanisms for raw and coagulated waters $[11,16,40,81,82]$. XPS has shown that in addition to reducing fouling by changing physical parameters such as increasing foulant effective size by aggregation, the inclusion of hydrogen bubbles in electrocoagulated flocs induces a larger uptake of hydrophobic compounds than during conventional chemical coagulation [79]. This was deduced by measuring higher peak areas indicative of hydrophobic bonds (i.e. $\underline{\mathrm{C}}-$ $\mathrm{C} / \underline{\mathrm{C}}-\mathrm{H}$ ) in electrocoagulated flocs in comparison with similar measurements of alum-coagulated flocs.

Electrochemically generated flocs at a concentration of $10 \mathrm{mg} \mathrm{Al} / \mathrm{L}$ were analyzed by XPS survey scans, which showed strong $\mathrm{C}, \mathrm{N}$, and $\mathrm{O}$ signals and high $\mathrm{O} / \mathrm{Al}$ ratios in the range $5-6$ (i.e. $>3$ from $\mathrm{Al}(\mathrm{OH})_{3(\mathrm{~s})}$ ), and have been attributed to sorbed NOM and bacteria [16]. The location and intensity of deconvoluted C, O, and N peaks in high resolution XPS scans can be used to infer NOM sorption during EC [16, 79]. For example, Figure 3 shows representative high resolution $\mathrm{X}$-ray spectra of $\mathrm{O} 1 \mathrm{~s}$ and $\mathrm{C}$ 1s photoelectrons from flocs formed by electrocoagulating

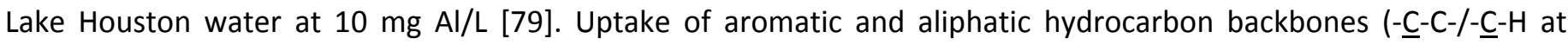
$284.95 \mathrm{eV})$, alcohols, phenols, and proteins (- $\underline{\mathrm{C}}-\mathrm{O}-/-\underline{\mathrm{C}}-\mathrm{N}-$ at $286.76 \mathrm{eV})$, aldehydes, ketones, amides, and (hemi)acetals $(-\underline{C}=\mathrm{O} /-\mathrm{O}-\underline{\mathrm{C}}-\mathrm{O}-$ at $288.58 \mathrm{eV})$, and humic acids, fulvic acids, and esters $(\underline{\mathrm{C}}(=\mathrm{O}) \mathrm{OH} / \underline{\mathrm{C}}(=\mathrm{O}) \mathrm{OR}$ at $289.25 \mathrm{eV})$ can be inferred from C1s core level spectra $[16,40,68,83,84]$. Similarly, sorption of carboxylates/carboxyl $\left(\mathrm{C}(=\underline{\mathrm{O}}) \mathrm{OH} / \mathrm{C}(=\underline{\mathrm{O}}) \mathrm{O}^{-}\right)$, esters $(\mathrm{C}(=\underline{\mathrm{O}}) \mathrm{OR})$, and amides $(\mathrm{C}(=\underline{\mathrm{O}}) \mathrm{N})$, hydroxides and (hemi)acetals $\left.\underline{(\mathrm{O}}-(\mathrm{C}, \mathrm{H})\right)$, and singly bonded oxygen in carboxyls $(C(=O) \underline{O} H)$ and esters $(C(=O) \underline{O})$ has been measured by decomposing the O1s core level peak at $531.68 \mathrm{eV}, 532.65 \mathrm{eV}$, and $533.72 \mathrm{eV}$ respectively as shown in Figure 3 [68, 79, 85]. Greater uptake of hydrophobic compounds during EC has been verified by gross NOM characteristics, e.g. lower UV ${ }_{254}$ absorbance 
values in EC/MF permeates compared with conventional alum coagulation pretreatment to MF [79].

During raw water $\mathrm{MF}$, it has been proposed that fouling is initiated by sorption of hydrophobic humic-like molecules present in the influent, which is then followed by more hydrophilic moieties causing the flux to decrease $[40,81]$. Any added electrocoagulant partitions a portion of the hydrophobic NOM reducing direct interactions of these molecules with the polymeric matrix of the membrane thereby controlling flux decline $[16,40]$. Although aluminum coagulation reduces fouling, $\mathrm{Al}(\mathrm{OH})_{3(\mathrm{~s})}$ accumulates on the membrane over long durations and can intensify complexation of hydrophilic molecules such as biopolymers on MF and UF membranes [11, 40, 82]. These results indicate that maximizing bubble surface area (e.g. by increasing bubble number and decreasing their size for the same $\mathrm{H}_{2(\mathrm{~g})}$ volume released) would be optimal MF pretreatment to increase hydrophobic interactions and NOM uptake onto flocs.
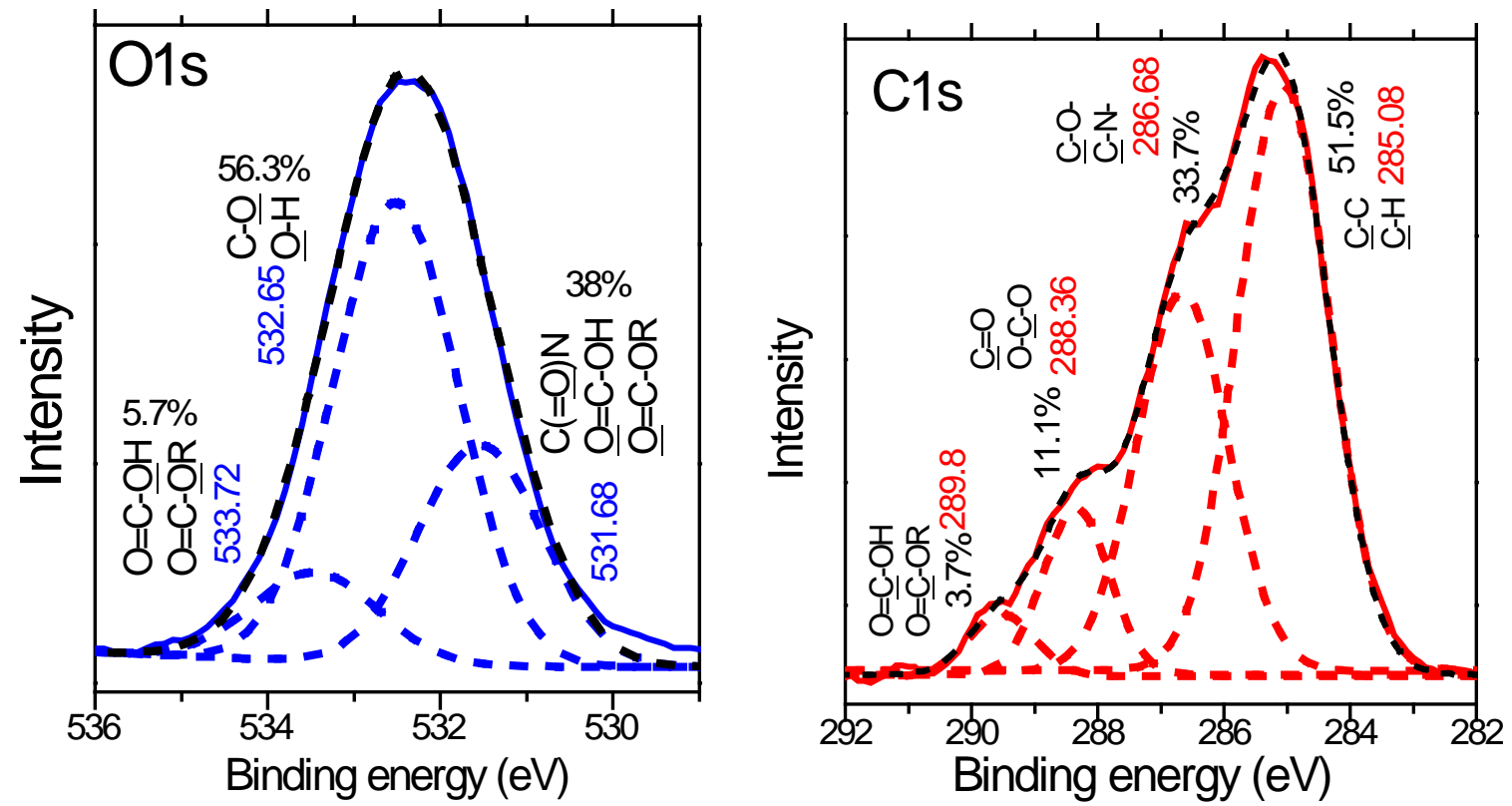

Figure 3. Examples of curve fitted high resolution XPS spectra before and after pretreatment. O1s core level peaks of raw (untreated) colloids in surface water are shown on the left. Deconvoluted C1s spectrum following electrochemical treatment is shown on the right. Adapted from [79].

\section{WATER QUALITY IMPROVEMENTS}

In aluminum EC/MF systems, membrane fouling is alleviated only up to a point where the electrocoagulant dosage is optimal, after which point fouling worsens if more coagulant is added $[16,39]$. Unlike fouling control, which is best controlled at an intermediate electrocoagulant dose, contaminant removal by the integrated system typically increases progressively as more and more electrocoagulant is added. It is emphasized that integral micro- and ultrafilters directly remove protozoa and bacteria even without any pretreatment because membrane pore sizes are 
about one order of magnitude smaller than these microorganisms $[4,86]$. Consequently, in this paper we focus only on NOM, DBP precursor, and virus control, which are not well-removed by MF/UF alone during drinking water treatment. The reader is referred elsewhere for the removal of other contaminants (e.g. trace metals and metalloids) by EC $[15,21,87]$.

5.1. NOM and DBP precursor control. Both aluminum and iron are effective electrocoagulants in enhancing NOM removal [37, 38, 40, 58, 88, 89]. Iron polymorphs show significant differences in NOM removal with green rust outperforming lepidocrocite and magnetite [51]. In addition to monitoring DOC, it is also useful to evaluate specific UV absorbance (SUVA, defined as the ratio of $\mathrm{UV}_{254}$ in $\mathrm{m}^{-1}$ and DOC concentration in $\mathrm{mg} / \mathrm{L}$ ) since SUVA is an indicator of NOM chemical composition and reactivity [90].

5.1.2. NOM removal and DBP precursor control results. DOC concentrations and $\mathrm{UV}_{254}$ values in $\mathrm{MF}$ permeate for a range of electrochemical aluminum dosages $(0-30 \mathrm{mg} / \mathrm{L})$ added to surface water are shown in Figure 4 at two $\mathrm{pH}$ values of 6.4 and 7.5. DOC concentrations (Figure $4 a$ ) and $U_{254}$ absorbance values (Figure $4 \mathrm{~b}$ ) in the EC/MF water can be seen to decrease progressively as more and more aluminum is added. Additionally, as depicted in Figure 4a, NOM removal is higher at $\mathrm{pH}$ 6.4. This is attributed to more effective charge neutralization (charge density $\rightarrow 0$ ) by the dominant hydrolysis product $\mathrm{Al}(\mathrm{OH})_{2}{ }^{+}$compared with $\mathrm{Al}(\mathrm{OH})_{4}{ }^{-}$at $\mathrm{pH} 7.5$, which formed more insoluble complexes and made NOM more adsorbable [91]. Since pH 6.4 approximately corresponds to minimum aluminum solubility [56, 92], NOM is also probably better enmeshed onto $\mathrm{Al}(\mathrm{OH})_{3}$ precipitates at 6.4. Also, UV-absorbing compounds are typically removed to a greater extent than DOC during coagulation [93]. Results summarized in Figure 4 are consistent with previous investigations of conventional chemical coagulation [93, 94] wherein aromatic, higher molecular weight, and hydrophobic humic components are also preferentially removed by EC [58, 95]. 

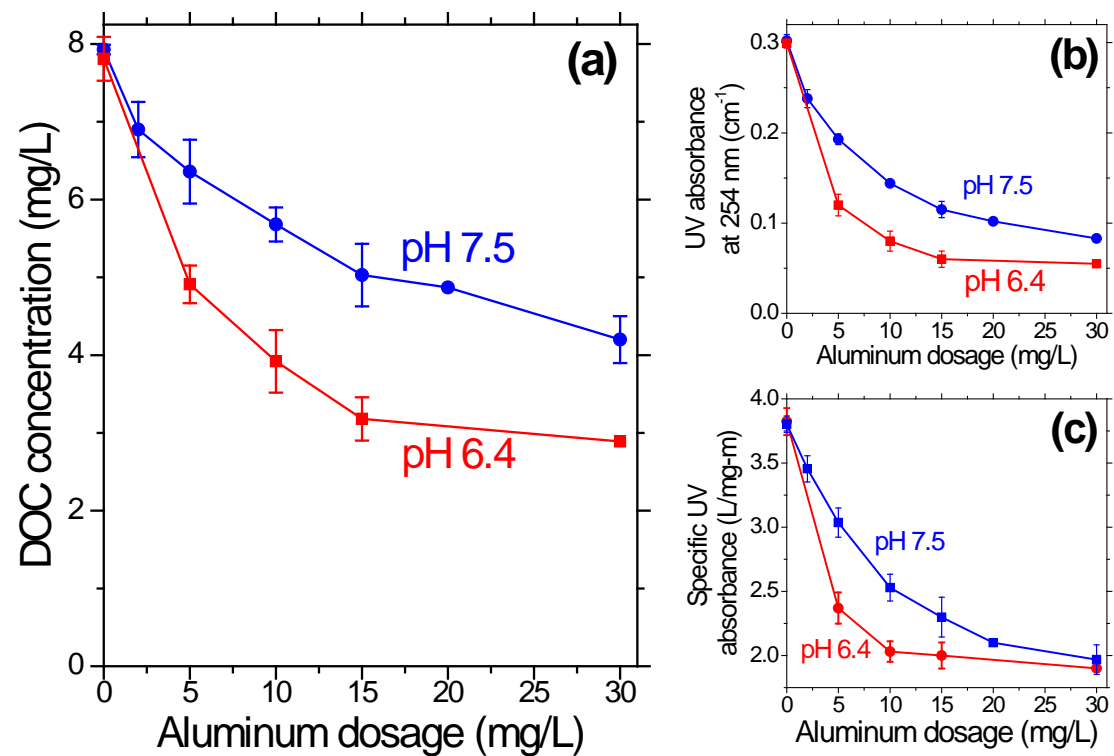

Figure 4. Improvements in NOM removal measured as dissolved organic carbon (a) and $\mathrm{UV}_{254}$ (b) as well as decreasing specific UV absorbance (c) through aluminum electrocoagulation pretreatment of Lake Houston water at pH 7.5 and 6.4.

SUVA, an indicator of NOM's reactivity towards chlorine [90], was also reduced by EC/MF as shown in Figure 4c. lower SUVA coupled with decreasing NOM molecular weight following EC/MF suggests that DBPs are controlled by reducing the absolute concentration of organic precursors as well as their reactivity. To our knowledge, earlier EC work has focused only on NOM removal e.g. $[37,38,51,58,88]$ and DBP formation has not yet been directly measured. Previously unpublished data presented in Figure 4 demonstrate that for example at $10 \mathrm{mg} / \mathrm{L}$ aluminum dosage, EC/MF removed $\sim 40 \% \mathrm{DOC}$ (from $6 \mathrm{mg} / \mathrm{L}$ to $3.58 \mathrm{mg} / \mathrm{L}$ ) and $52 \% \mathrm{UV}_{254}$ removal (from $0.117 \mathrm{~cm}^{-1}$ to $0.056 \mathrm{~cm}^{-}$ $\left.{ }^{1}\right)$ from Lake Houston. This resulted in 52\% removal of total SDS-THMs and $60 \%$ removal of SDS-HAA6. SUVA reduction by EC shown in Figure 4c correspondingly decreased SDS-THM and SDS-HAA specific yield ( $\mu$ M of DBPs produced per $\mathrm{mM}$ of $\mathrm{DOC}$ ) by $20 \%$ and $34 \%$ respectively. As discussed earlier, this can be attributed to the preferential removal of the hydrophobic and higher molecular weight fractions of NOM, which are generally accepted to be more reactive in forming DBPs coupled with a reduction in chlorine demand. Therefore, DBP control by $\mathrm{EC}$ appears to be achieved by removing precursors measured as $\mathrm{DOC}$ and $\mathrm{UV}_{254}$ and simultaneous reduction in reactivity of NOM with chlorine.

THM and HAA speciation during chlorination depends on the individual ratios of $\mathrm{NOM}$ present, $\mathrm{Cl}_{2}$ dosed, and $\mathrm{Br}$ concentration $[93,96]$. Electro- and alum coagulation changes $\mathrm{Br}^{-} / \mathrm{NOM}$ and $\mathrm{Cl}_{2} / \mathrm{NOM}$ ratios compared with the raw water since they preferentially remove NOM and not $\mathrm{Br}^{-}$. Therefore, EC cannot be expected to control individual THM and HAA species to the same extent. As expected, EC induced a slight shift towards brominated THM and HAA6 
species, which can be visualized by analyzing mole fractions (Figure 5). As seen, mole fractions of brominated THMs, $\mathrm{CHBrCl}_{2}, \mathrm{CHBr}_{2} \mathrm{Cl}$ and $\mathrm{CHBr}_{3}$ increased after $\mathrm{EC} / \mathrm{MF}$ and similar results were obtained for HAAs. In this case, the $\mathrm{Br}^{-}$ /DOC ratio was increasing from 0.028 to $0.045 \mu \mathrm{M} / \mu \mathrm{M}$ and simultaneously chlorine consumption was decreased by 42\%. This corresponds to a decrease in bromide utilization for both THMs and HAAs because excess $\mathrm{Br}^{-}$could not react once all available reactive sites on NOM were occupied, similar to changes in DBP speciation following nanofiltration discussed earlier [97]. On the other hand, EC significantly increased the bromine incorporation factor for THMs and HAAs attributed to initial formation of brominated DBPs since $\mathrm{HOBr}$ is a stronger halogenating agent than $\mathrm{HOCl}$.

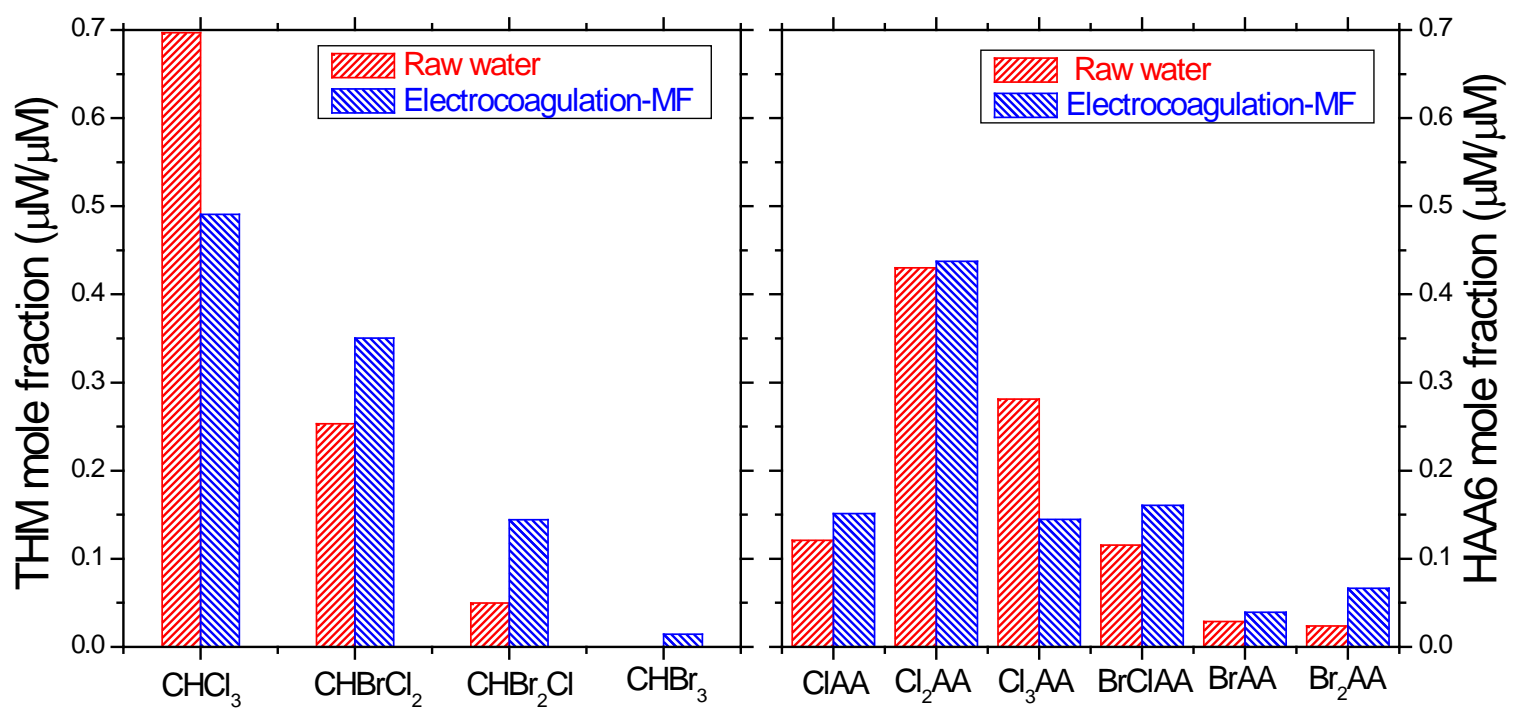

Figure 5. Changes in THM and HAA speciation following electrocoagulation - MF of Lake Houston water. Note the general shift towards brominated THM and HAA species after treatment.

5.2. Behavior of microorganisms in electrochemical systems. Electrodisinfection has been demonstrated using carbon, mixed metal oxides, boron doped diamond, and other dimensionally stable anodes largely using model waters not containing NOM [54, 98-101]. The primary advantage of purely electrochemical inactivation is that in situ disinfectant generation reduces the risk associated with transport and on-site storage of large amounts of highly toxic chemicals [102]. Inactivation in such systems occurs through generation of oxidants (e.g. chlorine) and free radical intermediates (e.g. reactive oxygen species) $[98,99,103]$. In contrast, as discussed earlier in this manuscript, EC is performed using sacrificial (not dimensionally stable) anodes and real-world surface waters contain NOM. It is emphasized that intact MF membranes alone have been shown to remove $>99.9999 \%$ (6-logs) of bacteria and protozoa simply due to size exclusion but they allow nearly unhindered virus passage $[6,44,46,104]$. Additionally, EC alone is highly effective for bacteria and algae control $[17,65,101]$. Hence, this review is focused largely towards 
microorganisms that are smaller than MF membrane pores (i.e. viruses).

Iron $\mathrm{EC} / \mathrm{MF}$ was initially shown to be more effective than conventional coagulation for virus removal from synthetic water devoid of NOM achieving $>4$ log removal (as required by the United States Environmental Protection Agency) at $10 \mathrm{mgFe} / \mathrm{L}$ dosage compared with only 2 log removal at an equivalent ferric chloride dosage [105]. However, we recently demonstrated that this trend is reversed for surface water containing $5 \mathrm{mg}-\mathrm{C} / \mathrm{L}$ NOM where EC/MF only removed 1.5 log of MS2 viruses at $13 \mathrm{mgFe} / \mathrm{L}$ whereas 6.5 log removal was measured from synthetic water at a similar iron dosage [44]. Presence of $5 \mathrm{mg}-\mathrm{C} / \mathrm{L}$ of Suwannee River Humic Acid (SRHA) decreased virus removal by approximately 4- $\log$ at $\mathrm{pH} 6.4$ and approximately 2-log at $\mathrm{pH} 7.5$ by $\mathrm{EC} / \mathrm{MF}$ compared to $\mathrm{FeSO}_{4}$ coagulation/MF [44]. Hence, it was hypothesized that NOM worsened virus removal by complexing electrodissolved Fe(II), inhibiting its oxidation to insoluble Fe(III) [63], and consequently reducing coagulant precipitation and sweep flocculation [44]. In contrast, it has been recently reported that $3 \mathrm{mg}-\mathrm{C} / \mathrm{L}$ of Suwannee River Fulvic Acid (SRFA) did not significantly influence Escherichia coli attenuation from synthetic groundwater [100]. Hence, the concentration and composition of NOM appears to play important roles in affecting microorganism removal/inactivation in surfaceand groundwaters. Additionally, viruses are inactivated by $\mathrm{Fe}(\mathrm{II})$ and $\mathrm{Fe}(0)$ (when no NOM is present) but the underlying mechanisms have not yet been undisputedly identified [106] although current evidence points to oxidative stress $[100,107]$. It is emphasized that the early favorable results on virus removal by iron EC/MF were obtained using synthetic waters with no NOM [105]. Apparently conflicting reports on NOM effects during iron EC for bacteria and viruses and between surface- and groundwater $[44,100]$ demonstrates the need for more research to systematically evaluate the role of NOM on the performance of iron EC/MF for treating NOM-laden surface waters.

All infective viruses taken up by flocs generated by conventional alum coagulation and aluminum EC of surface water has been recovered by dissolving them at high $\mathrm{pH}$ using beef extract (but not for polyaluminum chloride) [8, $46,108,109]$. Hence, unlike iron, aluminum electrolysis does not inactivate viruses under low-salinity conditions typical of natural water. Nevertheless, aluminum is more effective than iron in removing viruses from NOMcontaining surface waters (see Figure 6a) due to successful $\mathrm{Al}(\mathrm{OH})_{3(\mathrm{~s})}$ precipitation and enmeshment whereas iron did not significantly precipitate following electrolysis under these conditions [44, 46].

Insights into virus-floc interactions have been obtained via atomic force microscopy using tips with covalently immobilized viruses (see inset in Figure 6b) [46]. Unbinding force calculated from pull-off curves corresponding to the 
vertical retraction of virus-coated tips from the floc interface in a liquid cell are shown in Figure $6 b$ for $0,2,5$, and 20 $\mathrm{mgAl} / \mathrm{L}$ dosages. For the raw water and the lowest dose studied $(2 \mathrm{mg} / \mathrm{L})$, there was negligible interactions between the tip and the flocs leading to poor removals by EC. Higher dosages caused viruses to adhere strongly and multiple peaks were observed as the tip was retracted from the floc surface in the contact mode. Multiple pull-off events correspond to interactions of capsid proteins of viruses on the tip with $\mathrm{NOM}$, viruses, and $\mathrm{Al}(\mathrm{OH})_{3}$ precipitates (including polyvalent cations bridges) as well as formation and breakage of intra-protein bonds as the virus is pulled [110]. Fluorescence microscopy also has provided visual evidence for virus enmeshment during EC [46]. EF of cyanobacteria by taking advantage of its positive buoyancy (with no inactivation) has also been to be successful for algae removal [65].
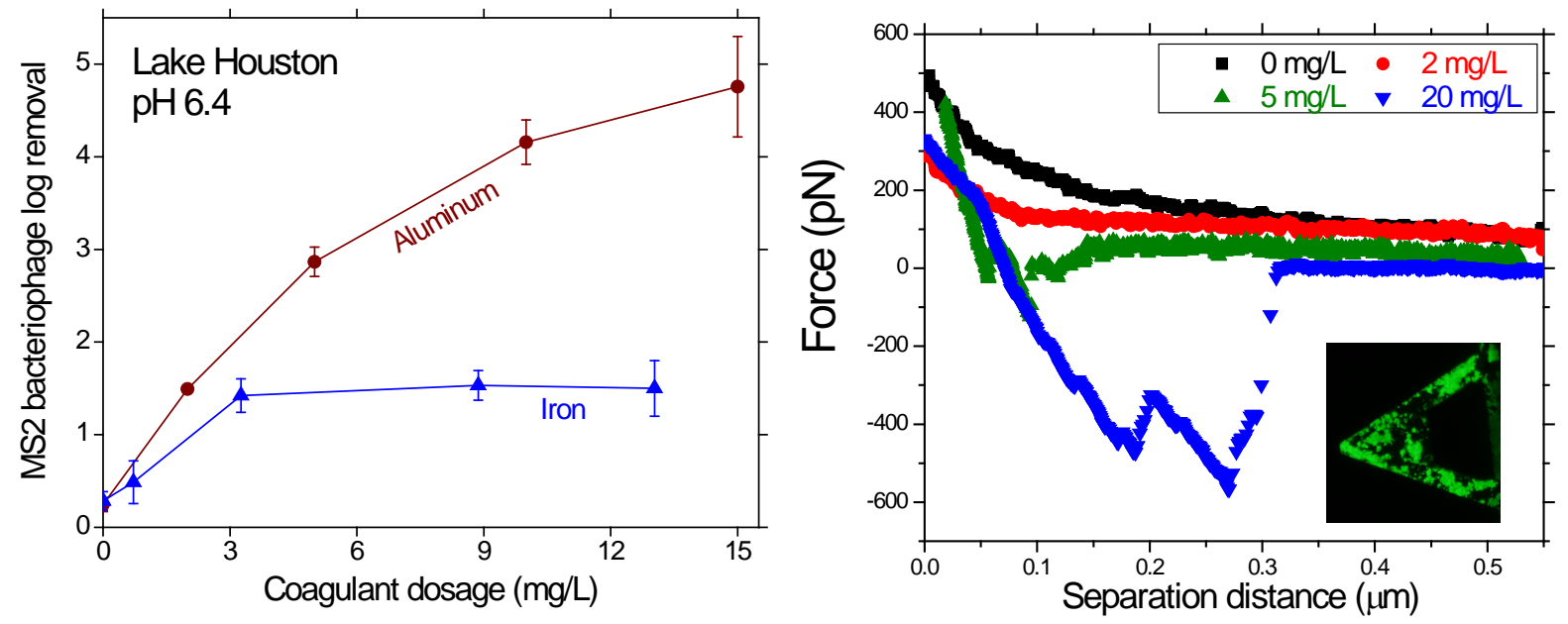

Figure 6. Aluminum electrocoagulation removes viruses from surface water to a greater extent than iron (left). AFM pull-off curves during for the retraction of virus-coated tips from the surfaces of $\mathrm{Al}(\mathrm{OH}) 3$ flocs formed during electrocoagulation of lake Houston water. Fluorescent image of viruses bonded on Si3N4 tips using 3-aminopropyl-triethoxysilane (APTES) is shown in the inset on the right. Adapted from $[44,46]$.

An issue specific to integrated EC/MF treatment is the potential effect of a foulant layer on further removal of viruses. Previously deposited colloids do indeed serve as a secondary filter to increase observed (not intrinsic) rejection $[44,46,111,112]$ but the magnitude depends on the nature of viruses and coagulation conditions. For example, by precoating a MF membrane with precipitates produced by polyaluminum chloride coagulant, improvements in virus log-removal has been measured in the order MS2 $>Q \beta>$ recombinant norovirus virus-like particles [111]. This effect is more prominent at higher dosages for both iron and aluminum EC [44, 46]. Reanalyzing recently published data from our research group [46] demonstrates a strong positive correlation with cake mass at different dosages as shown in Figure 7. Hence, it appears that thick cake layers can function as dynamic membranes 
[113] to remove viruses by an additional 1-log compared with the identical coagulant dosage without cake formation. It should be noted that pore blocking can also contribute to secondary virus removal both in raw and precoagulated waters; i.e. both reversible and irreversible fouling contribute to measured enhancements in microorganism removal [114].

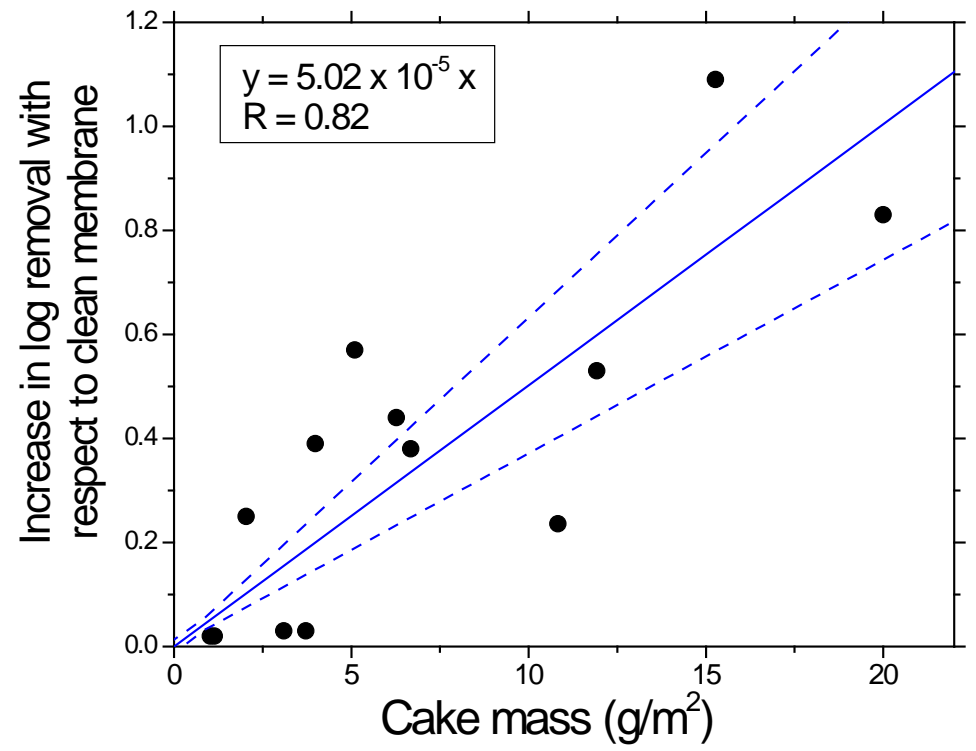

Figure 7. Additional removal of the MS2 bacteriophage due to cake formation during aluminum EC/MF (adapted from [46]).

Figure 8 depicts a reanalysis of our recently published data during EC/MF of Lake Houston water $(10 \mathrm{mg} / \mathrm{L}$ and pH 6.4) over a period of 5 hours [46]. The brown and blue symbols correspond to Fe and Al respectively, which demonstrate statistically similar concentrations of infective viruses. Relatively constant virus concentrations measured by the plaque assay demonstrates no inactivation in the presence of NOM as discussed earlier. However, unlike surface waters with low-salinity, EC of brackish waters can oxidize chloride ions at the anode to free chlorine $[17,101]$, which is a strong oxidant/disinfectant capable of inactivating microorganisms:

$$
2 \mathrm{Cl}^{-} \rightarrow \mathrm{Cl}_{2}+2 \mathrm{e}^{-} ; \mathrm{Cl}_{2}+\mathrm{H}_{2} \mathrm{O} \leftrightarrow \mathrm{HOCl}+\mathrm{H}^{+}+\mathrm{Cl}^{-} ; \mathrm{HOCl} \leftrightarrow \mathrm{H}^{+}+\mathrm{OCl}^{-}
$$

Algae and virus control is enhanced at high chloride ion concentrations due to chlorine-induced inactivation on top of physical removal by coagulation $[17,45]$. This is also depicted in Figure 8 , which shows decreasing infectivity of the MS2 virus during electrolysis of synthetic water containing high chloride ion concentrations but lacking NOM (green and red curves). Under these conditions approximately $0.02 \mathrm{mg} \mathrm{Cl} / \mathrm{L}$ was measured resulting in $1-1.5 \log$ inactivation during the first hour. However, shielding and aggregation within flocs significantly slows down disinfection kinetics reaching only 2 log inactivation after 5 hours. Hence, physical removal dominates inactivation for overall microorganism control corresponding to residence times typical of electrochemical treatment [45]. Chlorine is 
also expected to react with any NOM that may be present in natural water. Hence, artificially extended flocculation/contact times would be necessary to achieve significant inactivation during iron/aluminum EC of surface water.

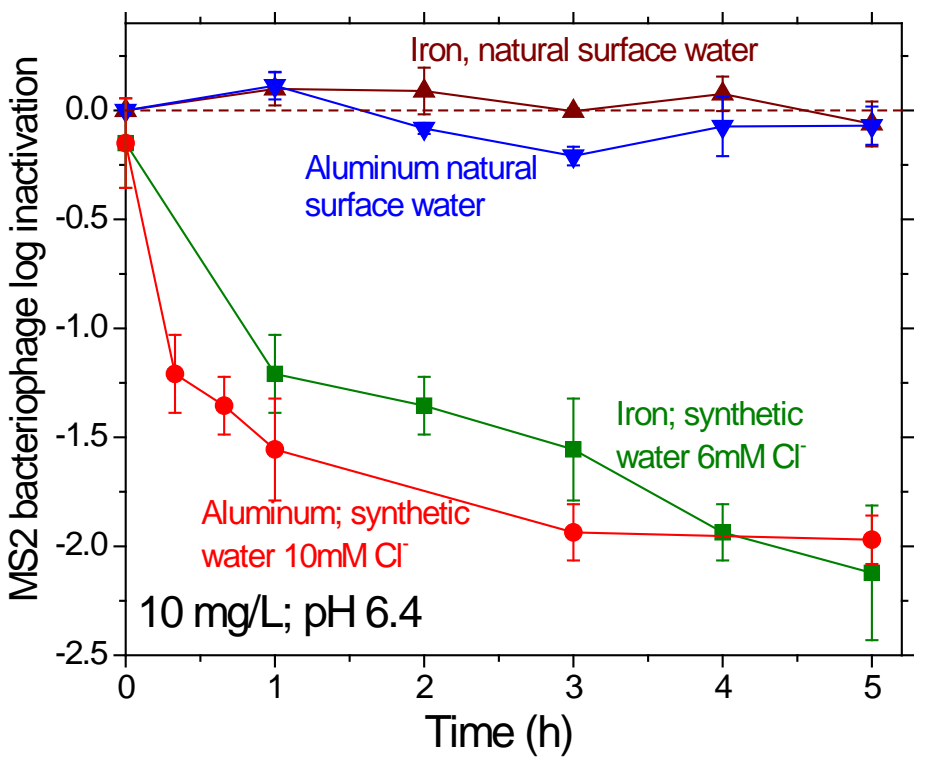

Figure 8. Viruses are not inactivated during electrocoagulation of NOM-laden surface water. The MS2 bacteriophage loses infectivity during electrolysis of chloride-rich synthetic waters that do not contain NOM. Adapted from [44, 45].

In addition to being disinfectant precursors, chloride ions also attack the passivation layer on sacrificial electrodes enhancing coagulant chemical dissolution due to pitting corrosion. This can result in super-Faradaic coagulant dissolution, in excess of Equation 2 predictions $[53,64,115]$. In contrast, accumulation of precipitates and other contaminants on electrode surfaces can result in sub-Faradaic coagulant dissolution lower than Equation 3 predictions [32]. Reversing the polarity (by using sacrificial anodes and cathodes) and increasing tangential shear (similar to crossflow filtration) can potentially reduce such problems related to unpredictable or changing coagulant dosing over time $[32,50]$.

\section{CONCLUDING REMARKS}

In this manuscript, we mainly reviewed data generated in our research group regarding the integration of aluminum EC and MF for drinking water treatment while including limited information on iron EC/MF. It is shown that aluminum EC significantly reduces MF fouling by inducing the formation of a cake comprised of particles larger than in the raw water. However, aluminum flocs can compact or compress and relatively worsen MF fouling at higher pressures. New results are also included showing significant improvements in microfiltered water quality by EC pretreatment. $\mathrm{Al}(\mathrm{OH})_{3}$ flocs sorb NOM and DBP precursors, which are then retained on the MF membrane surface. 
EC/MF induces a slight shift towards brominated THMs and HAAs by increasing the $\mathrm{Br}^{-} / \mathrm{DOC}$ ratio compared to the raw water. It is also shown that viruses are effectively sweep coagulated by EC and removed subsequently by MF. A thick cake layer of $\mathrm{Al}(\mathrm{OH})_{3}$ flocs further improved virus removal by acting as a dynamic membrane. In summary, results presented herein suggest that EC/MF systems are promising alternatives for small-scale decentralized facilities because they inherently provide multiple barriers against contaminants of health concern and minimize membrane fouling while requiring limited operator attention [116].

Although the concept of employing electrical current to dissolve coagulants and generate oxidants in situ has a long history, EC has not yet obtained a firm foothold in water/wastewater treatment. Recently, much progress has been made to elucidate various performance aspects including $\mathrm{pH}$ profiles between electrodes, precipitated solid phases, electrode passivation, and other factors influencing EC performance. However, much more work needs to be done since a universal understanding of the nature and composition of precipitated phases based on water chemistry and electrolysis conditions continues to remain elusive. Additionally, preliminary cost estimates suggest that EC is competitive to conventional coagulation especially for smaller installations [33]. Importantly, electrochemical treatment does not consume buffering capacity unlike hydrolyzing metal salt coagulants that behave as Brønsted acids. Hence, EC may be suitable for a wide range of water chemistries and eliminates the need to add base to maintain $\mathrm{pH}$ during coagulation (leading to reduced chemical handling and increased process simplicity). Improved designs incorporating multiple electrode configurations have also been proposed $[15,57,87]$. These indicate the growing interest in electrochemical and MF technologies especially for small, portable systems for localized treatment [116].

However, electrode passivation [53] and inconsistent coagulant dosing over long periods of operation [117] continues to impede EC, in the same sense that fouling still limits MF application. Research is being actively conducted to identify solid phases and dissolved hydrolysis products in electrochemical cells $[51,55,66]$ since this intimately impacts contaminant removal and subsequent MF performance. However, more work remains to be done in order to predict the precipitate morphology and composition based on background water chemistry and EC operating conditions. Such knowledge would benefit our understanding of contaminant removal and fouling control by EC and future design of hybrid EC/MF systems. It is hypothesized that compressibility indices would depend on the nature of the solid phase, which in turn would strongly influence MF flux and fouling. It is emphasized that more 
work is necessary to carefully delineate electrocoagulant species which may be different than in chemical coagulation

because of inherent disparities in the microenvironment at the anode-water interface compared with alum addition (although work is being done for the case of iron e.g. $[118,119])$. Specific interactions of hydrolysis products with polymeric MF membranes also need to be measured to estimate (ir)reversible fouling. Further, long-term pilot-scale on-site evaluations for individual applications are necessary to build an empirical database for integrated EC/MF treatment in parallel to developing a more detailed understanding of underlying mechanisms and best design practices.

Acknowledgements. We appreciate funding from the Bureau of Reclamation (R14AP00152) and the National Science Foundation (CBET 1510526), very detailed reviews of anonymous referees during the peer-review process, and the assistance of former Ph.D. students Neranga Gamage and Charan Tanneru.

\section{REFERENCES}

1. United Nations. http://www.un.org/waterforlifedecade/scarcity.shtml. 2014 [cited 2015 April 22].

2. Coplin, L.S. and D. Galloway, Chapter 7. Houston-Galveston, Texas: Managing coastal subsidence, in Land Subsidence in the United States, D. Galloway, D.R. Jones, and S.E. Ingebritsen, Editors. 1999, U.S. Department of the Interior and U.S. Geological Survey: Reston, VA. p. 35-48.

3. Letterman, R.D., ed. Water Quality and Treatment: A Handbook of Community Water Supplies. $5^{\text {th }}$ Edition ed. 1999, McGraw Hill, Inc.: New York.

4. Hoek, E.M.V. and V.V. Tarabara, eds. Encyclopedia of Membrane Science and Technology. 2013, John Wiley \& Sons, Inc. : New York, N.Y.

5. Xagoraraki, I., Z.Q. Yin, and Z. Svambayev, Fate of Viruses in Water Systems. Journal of Environmental Engineering, 2014. 140(7): p. Article number 04014020.

6. Antony, A., J. Blackbeard, and G. Leslie, Removal Efficiency and Integrity Monitoring Techniques for Virus Removal by Membrane Processes. Critical Reviews in Environmental Science and Technology, 2012. 42(9): $p$. 891-933.

7. Zhu, B.T., D.A. Clifford, and S. Chellam, Virus removal by iron coagulation-microfiltration. Water Research, 2005. 39(20): p. 5153-5161.

8. Meyn, T., T.O. Leiknes, and A. Konig, MS2 removal from high NOM content surface water by coagulation ceramic microfiltration for potable water production. AIChE Journal, 2012. 58(7): p. 2270-2281.

9. Shirasaki, N., I. Matsushita, Y. Matsui, M. Kobuke, and K. Ohno, Comparison of removal performance of two surrogates for pathogenic waterborne viruses, bacteriophage $Q \beta$ and MS2, in a coagulation-ceramic microfiltration system. Journal of Membrane Science, 2009. 326(2): p. 564-571.

10. Chellam, S. and J.G. Jacangelo, Existence of Critical Recovery and Impacts of Operational Mode on Potable Water Microfiltration. Journal of Environmental Engineering, 1998. 124(12): p. 1211-1219.

11. Kimura, K., K. Tanaka, and Y. Watanabe, Microfiltration of different surface waters with/without coagulation: Clear correlations between membrane fouling and hydrophilic biopolymers. Water Research, 2014. 49: p. 434443.

12. Molgora, C.C., A.M. Dominguez, E.M. Avila, P. Drogui, and G. Buelna, Removal of arsenic from drinking water: A comparative study between electrocoagulation-microfiltration and chemical coagulation-microfiltration processes. Separation and Purification Technology, 2013. 118: p. 645-651.

13. Wiesner, M.R. and J.-M. Laine, Coagulation and Membrane Separation, in Water Treatment Membrane Processes, J. Mallevialle, P.E. Odendaal, and M.R. Wiesner, Editors. 1996, McGraw Hill: New York, N.Y. p. 16.1-16.12. 
14. Jimenez, C., C. Saez, F. Martinez, P. Canizares, and M.A. Rodrigo, Electrochemical dosing of iron and aluminum in continuous processes: $A$ key step to explain electro-coagulation processes. Separation and Purification Technology, 2012. 98: p. 102-108.

15. Chen, G., Electrochemical technologies in wastewater treatment. Separation and Purification Technology, 2004. 38(1): p. 11-41.

16. Gamage, N.P., J.D. Rimer, and S. Chellam, Improvements in permeate flux by aluminum electroflotation pretreatment during microfiltration of surface water. Journal of Membrane Science, 2012. 411-412: p. 45-53.

17. Gao, S.S., M.A. Du, J.Y. Tian, J.Y. Yang, J.X. Yang, F. Ma, and J. Nan, Effects of chloride ions on electrocoagulation-flotation process with aluminum electrodes for algae removal. Journal of Hazardous Materials, 2010. 182(1-3): p. 827-834.

18. Matis, K.A. and E.N. Peleka, Alternative Flotation Techniques for Wastewater Treatment: Focus on Electroflotation. Separation Science and Technology, 2010. 45(16): p. 2465-2474.

19. Harif, T., M. Khai, and A. Adin, Electrocoagulation versus chemical coagulation: Coagulation/flocculation mechanisms and resulting floc characteristics. Water Research, 2012. 46(10): p. 3177-3188.

20. Moreno, H.A., D.L. Cocke, J.A.G. Gomes, P. Morkovsky, J.R. Parga, E. Peterson, and C. Garcia, Electrochemical Reactions for Electrocoagulation Using Iron Electrodes. Industrial \& Engineering Chemistry Research, 2009. 48(4): p. 2275-2282.

21. Wan, W., T.J. Pepping, T. Banerji, S. Chaudhari, and D.E. Giammar, Effects of water chemistry on arsenic removal from drinking water by electrocoagulation. Water Research, 2011. 45(1): p. 384-392.

22. Mohora, E., S. Rončević, B. Dalmacija, J. Agbaba, M. Watson, E. Karlović, and M. Dalmacija, Removal of natural organic matter and arsenic from water by electrocoagulation/flotation continuous flow reactor. Journal of Hazardous Materials, 2012. 235-236(0): p. 257-264.

23. Yıldız, Y.S.., A.S. Koparal, and B. Keskinler, Effect of initial pH and supporting electrolyte on the treatment of water containing high concentration of humic substances by electrocoagulation. Chemical Engineering Journal, 2008. 138(1-3): p. 63-72.

24. Vepsäläinen, M., M. Pulliainen, and M. Sillanpää, Effect of electrochemical cell structure on natural organic matter (NOM) removal from surface water through electrocoagulation (EC). Separation and Purification Technology, 2012. 99(0): p. 20-27.

25. Vasudevan, S., J. Lakshmi, and G. Sozhan, Effects of alternating and direct current in electrocoagulation process on the removal of cadmium from water. Journal of Hazardous Materials, 2011. 192(1): p. 26-34.

26. Hanay, O. and $\mathrm{H}$. Hasar, Effect of anions on removing $\mathrm{Cu} 2+, \mathrm{Mn} 2+$ and $\mathrm{Zn2}+$ in electrocoagulation process using aluminum electrodes. Journal of Hazardous Materials, 2011. 189(1-2): p. 572-576.

27. Khatibikamal, V., A. Torabian, F. Janpoor, and G. Hoshyaripour, Fluoride removal from industrial wastewater using electrocoagulation and its adsorption kinetics. Journal of Hazardous Materials, 2010. 179(1-3): p. 276280.

28. Kilic, M.G. and C. Hosten, A comparative study of electrocoagulation and coagulation of aqueous suspensions of kaolinite powders. Journal of Hazardous Materials, 2010. 176(1-3): p. 735-740.

29. Lee, S.Y. and G.A. Gagnon, Review of the factors relevant to the design and operation of an electrocoagulation system for wastewater treatment. Environmental Reviews, 2014. 22(4): p. 421-429.

30. Barrera-Diaz, C., B. Bilyeu, G. Roa, and L. Bernal-Martinez, Physicochemical Aspects of Electrocoagulation. Separation and Purification Reviews, 2011. 40(1): p. 1-24.

31. Balasubramanian, N., T. Kojima, C.A. Basha, and C. Srinivasakannan, Removal of arsenic from aqueous solution using electrocoagulation. Journal of Hazardous Materials, 2009. 167(1-3): p. 966-969.

32. Timmes, T.C., H.C. Kim, and B.A. Dempsey, Electrocoagulation pretreatment of seawater prior to ultrafiltration: Pilot-scale applications for military water purification systems. Desalination, 2010. 250(1): p. 613.

33. Timmes, T.C., H.-C. Kim, and B.A. Dempsey, Electrocoagulation pretreatment of seawater prior to ultrafiltration: Bench-scale applications for military water purification systems. Desalination, 2009. 249(3): p. 895-901.

34. Ben-Sasson, M. and A. Adin, Fouling mechanisms and energy appraisal in microfiltration pretreated by aluminum-based electroflocculation. Journal of Membrane Science, 2010. 352(1-2): p. 86-94.

35. Ben-Sasson, M. and A. Adin, Fouling mitigation by iron-based electroflocculation in microfiltration: Mechanisms and energy minimization. Water Research, 2011. 44(13): p. 3973-3981. 
36. Ben-Sasson, M., Y.M. Lin, and A. Adin, Electrocoagulation-membrane filtration hybrid system for colloidal fouling mitigation of secondary-effluent. Separation and Purification Technology, 2011. 82: p. 63-70.

37. Ben-Sasson, M., Y. Zidon, R. Calvo, and A. Adin, Enhanced removal of natural organic matter by hybrid process of electrocoagulation and dead-end microfiltration. Chemical Engineering Journal, 2013. 232: p. 338345.

38. Bagga, A., S. Chellam, and D.A. Clifford, Evaluation of iron chemical coagulation and electrocoagulation pretreatment for surface water microfiltration. Journal of Membrane Science, 2008. 309(1-2): p. 82-93.

39. Gamage, N.P. and S. Chellam, Aluminum electrocoagulation pretreatment reduces fouling during surface water microfiltration. Journal of Membrane Science, 2011. 379(1-2): p. 97-105.

40. Gamage, N.P. and S. Chellam, Mechanisms of Physically Irreversible Fouling during Surface Water Microfiltration and Mitigation by Aluminum Electroflotation Pretreatment. Environmental Science \& Technology, 2014. 48(2): p. 1148-1157.

41. Lakshmanan, D., D.A. Clifford, and G. Samanta, Ferrous and Ferric Ion Generation During Iron Electrocoagulation. Environmental Science \& Technology, 2009. 43(10): p. 3853-3859.

42. Li, L., C.M. van Genuchten, S.E.A. Addy, J.J. Yao, N.Y. Gao, and A.J. Gadgil, Modeling As(III) Oxidation and Removal with Iron Electrocoagulation in Groundwater. Environmental Science \& Technology, 2012. 46(21): p. 12038-12045.

43. Sari, M.A. and S. Chellam, Surface water nanofiltration incorporating (electro) coagulation-microfiltration pretreatment: Fouling control and membrane characterization. Journal of Membrane Science, 2013. 437(0): p. 249-256.

44. Tanneru, C.T. and S. Chellam, Mechanisms of virus control during iron electrocoagulation - Microfiltration of surface water. Water Research, 2012. 46(7): p. 2111-2120.

45. Tanneru, C.T., J. Narayanan, V.R. Hill, and S. Chellam, Relative insignificance of virus inactivation during aluminum electrocoagulation of saline waters. Environmental Science \& Technology, 2014. 48(24): p. 1459014598.

46. Tanneru, C.T., J.D. Rimer, and S. Chellam, Sweep Flocculation and Adsorption of Viruses on Aluminum Flocs during Electrochemical Treatment Prior to Surface Water Microfiltration. Environmental Science \& Technology, 2013. 47(9): p. 4612-4618.

47. Chellam, S. and N.G. Cogan, Colloidal and bacterial fouling during constant flux microfiltration: Comparison of classical blocking laws with a unified model combining pore blocking and EPS secretion. Journal of Membrane Science, 2011. 382(1-2): p. 148-157.

48. Xu, W.D. and S. Chellam, Initial stages of bacterial fouling during dead-end microfiltration. Environmental Science \& Technology, 2005. 39(17): p. 6470-6476.

49. Bowen, W.R., J.I. Calvo, and A. Hernandez, Steps of Membrane Blocking in Flux Decline during Protein Microfiltration. Journal of Membrane Science, 1995. 101(1-2): p. 153-165.

50. Cañizares, P., C. Jimenez, F. Martinez, C. Saez, and M.A. Rodrigo, Study of the Electrocoagulation Process Using Aluminum and Iron Electrodes. Industrial \& Engineering Chemistry Research, 2007. 46(19): p. 61896195.

51. Dubrawski, K.L. and M. Mohseni, In-situ identification of iron electrocoagulation speciation and application for natural organic matter (NOM) removal. Water Research, 2013. 47(14): p. 5371-5380.

52. Ben-Sasson, M., W. Calmano, and A. Adin, Iron-oxidation processes in an electroflocculation (electrocoagulation) cell. Journal of Hazardous Materials, 2009. 171(1-3): p. 704-709.

53. Mechelhoff, M., G.H. Kelsall, and N.J.D. Graham, Electrochemical behaviour of aluminium in electrocoagulation processes. Chemical Engineering Science, 2013. 95: p. 301-312.

54. Ghernaout, D., Advanced oxidation phenomena in electrocoagulation process: a myth or a reality? Desalination and Water Treatment, 2013. 51(40-42): p. 7536-7554.

55. Canizares, P., F. Martinez, C. Jimenez, J. Lobato, and M.A. Rodrigo, Comparison of the aluminum speciation in chemical and electrochemical dosing processes. Industrial \& Engineering Chemistry Research, 2006. 45(26): $p$. 8749-8756.

56. Davis, C.C. and M. Edwards, Coagulation With Hydrolyzing Metal Salts: Mechanisms and Water Quality Impacts. Critical Reviews in Environmental Science and Technology, 2014. 44(4): p. 303-347. 
57. Gomes, J.A.G., P. Daida, M. Kesmez, M. Weir, H. Moreno, J.R. Parga, G. Irwin, H. McWhinney, T. Grady, E. Peterson, and D.L. Cocke, Arsenic removal by electrocoagulation using combined Al-Fe electrode system and characterization of products. Journal of Hazardous Materials, 2007. 139(2): p. 220-231.

58. Dubrawski, K.L., M. Fauvel, and M. Mohseni, Metal type and natural organic matter source for direct filtration electrocoagulation of drinking water. Journal of Hazardous Materials, 2013. 244: p. 135-141.

59. Stumm, W. and J.J. Morgan, Aquatic chemistry: Chemical equilibria and rates in natural waters. $2^{\text {nd }}$ ed. 1996, New York: Wiley.

60. Gu, Z., Z. Liao, M. Schulz, J.R. Davis, J.C. Baygents, and J. Farrell, Estimating Dosing Rates and Energy Consumption for Electrocoagulation Using Iron and Aluminum Electrodes. Industrial \& Engineering Chemistry Research, 2009. 48(6): p. 3112-3117.

61. Amrose, S., A. Gadgil, V. Srinivasan, K. Kowolik, M. Muller, J. Huang, and R. Kostecki, Arsenic removal from groundwater using iron electrocoagulation: Effect of charge dosage rate. Journal of Environmental Science and Health Part a-Toxic/Hazardous Substances \& Environmental Engineering, 2013. 48(9): p. 1019-1030.

62. Dubrawski, K.L., C.M. van Genuchten, C. Delaire, S.E. Amrose, A.J. Gadgil, and M. Mohseni, Production and Transformation of Mixed-Valent Nanoparticles Generated by Fe(O) Electrocoagulation. Environmental Science \& Technology, 2015. 49(4): p. 2171-2179.

63. Theis, T.L. and P.C. Singer, Complexation of iron(II) by organic matter and its effect on iron(II) oxygenation. Environmental Science \& Technology, 1974. 8(6): p. 569-573.

64. Mouedhen, G., M. Feki, M.D.P. Wery, and H.F. Ayedi, Behavior of aluminum electrodes in electrocoagulation process. Journal of Hazardous Materials, 2008. 150(1): p. 124-135.

65. Gao, S.S., J.X. Yang, J.Y. Tian, F. Ma, G. Tu, and M.A. Du, Electro-coagulation-flotation process for algae removal. Journal of Hazardous Materials, 2010. 177(1-3): p. 336-343.

66. Ricordel, C., A. Darchen, and D. Hadjiev, Electrocoagulation-electroflotation as a surface water treatment for industrial uses. Separation and Purification Technology, 2010. 74(3): p. 342-347.

67. van Genuchten, C.M., S.E.A. Addy, J. Pena, and A.J. Gadgil, Removing Arsenic from Synthetic Groundwater with Iron Electrocoagulation: An Fe and As K-Edge EXAFS Study. Environmental Science \& Technology, 2012. 46(2): p. 986-994.

68. Crist, V.B., Handbook of Monochromatic XPS spectra. Vol. 2. 2005, California: XPS International LLC.

69. Masion, A., J.Y. Bottero, F. Thomas, and D. Tchoubar, Chemistry and Structure of Al(OH)/Organics Precipitates. A Small-Angle X-ray Scattering Study. 2. Speciation and Structure of the Aggregates. Langmuir, 1994. 10(11): p. 4349-4352.

70. Howe, K.J. and M.M. Clark, Effect of coagulation pretreatment on membrane filtration performance. Journal of the American Water Works Association, 2006. 98(4): p. 133-146.

71. Howe, K.J., A. Marwah, K.-P. Chiu, and S.S. Adham, Effect of Coagulation on the Size of MF and UF Membrane Foulants. Environmental Science \& Technology, 2006. 40(24): p. 7908-7913.

72. Wang, J., J. Guan, S.R. Santiwong, and T.D. Waite, Effect of aggregate characteristics under different coagulation mechanisms on microfiltration membrane fouling. Desalination, 2010. 258(1-3): p. 19-27.

73. Chellam, S. and W. Xu, Blocking laws analysis of dead-end constant flux microfiltration of compressible cakes. Journal of Colloid and Interface Science, 2006. 301(1): p. 248-257.

74. Belfort, G., R.H. Davis, and A.L. Zydney, The behavior of suspensions and macromolecular solutions in crossflow microfiltration. Journal of Membrane Science, 1994. 96(1-2): p. 1-58.

75. Lee, D.J., S.P. Ju, J.H. Kwon, and F.M. Tiller, Filtration of highly compactible filter cake: Variable internal flow rate. AIChE Journal, 2000. 46(1): p. 110-118.

76. Tiller, F.M. and J.H. Kwon, Role of porosity in filtration: XIII. Behavior of highly compactible cakes. AIChE Journal, 1998. 44(10): p. 2159-2167.

77. Chellam, S. and W.D. Xu, Blocking laws analysis of dead-end constant flux microfiltration of compressible cakes. Journal of Colloid and Interface Science, 2006. 301(1): p. 248-257.

78. Harif, T. and A. Adin, Size and structure evolution of kaolin-Al(OH)3 flocs in the electroflocculation process: $A$ study using static light scattering. Water Research, 2011. 45(18): p. 6195-6206.

79. Gamage, N.P., Electrocoagulation Pretreatment for Microfiltration of Surface Water: Mechanisms of Fouling and its Control, in Civil and Environmental Engineering. 2014, University of Houston: Houston, TX.

80. Lee, S.A., A.G. Fane, and T.D. Waite, Impact of Natural Organic Matter on Floc Size and Structure Effects in Membrane Filtration. Environmental Science \& Technology, 2005. 39(17): p. 6477-6486. 
81. Yamamura, H., K. Kimura, and Y. Watanabe, Mechanism Involved in the Evolution of Physically Irreversible Fouling in Microfiltration and Ultrafiltration Membranes Used for Drinking Water Treatment. Environmental Science \& Technology, 2007. 41(19): p. 6789-6794.

82. Tian, J.-y., M. Ernst, F. Cui, and M. Jekel, Correlations of relevant membrane foulants with UF membrane fouling in different waters. Water Research, 2013. 47(3): p. 1218-1228.

83. Echlin, P., Analysis of organic and biological surfaces. Chemical Analysis, ed. P.J. Elving, J.D. Winefordner, and I.M. Kolthoff. 1984, New York:: Wiley.

84. Naumkin, A.V., A. Kraut-Vass, S.W. Gaarenstroom, and C.J. Powell, NIST X-ray Photoelectron Spectroscopy Database 2012, National Institute of Standards and Technology (NIST).

85. Watts, J.F. and J. Wolstenholme, An Introduction to Surface Analysis by XPS and AES. 2003, Chichester, West Sussex, England: J. Wiley.

86. Jacangelo, J.G., S.S. Adham, and J.M. Laine, Mechanism of Cryptosporidium, Giardia, and MS2 virus removal by MF and UF. Journal American Water Works Association, 1995. 87(9): p. 107-121.

87. Mollah, M.Y.A., P. Morkovsky, J.A.G. Gomes, M. Kesmez, J. Parga, and D.L. Cocke, Fundamentals, present and future perspectives of electrocoagulation. Journal of Hazardous Materials, 2004. 114(1-3): p. 199-210.

88. Dubrawski, K.L. and M. Mohseni, Standardizing electrocoagulation reactor design: Iron electrodes for NOM removal. Chemosphere, 2013. 91(1): p. 55-60.

89. Ulu, F., S. Barisci, M. Kobya, and M. Sillanpaa, An evaluation on different origins of natural organic matters using various anodes by electrocoagulation. Chemosphere, 2015. 125: p. 108-114.

90. Weishaar, J.L., G.R. Aiken, B.A. Bergamaschi, M.S. Fram, R. Fujii, and K. Mopper, Evaluation of Specific Ultraviolet Absorbance as an Indicator of the Chemical Composition and Reactivity of Dissolved Organic Carbon. Environmental Science \& Technology, 2003. 37(20): p. 4702-4708.

91. Krasner, S.W. and G. Amy, Jar-test evaluations of enhanced coagulation. Journal American Water Works Association, 1995. 87(10): p. 93-107.

92. Canizares, P., C. Jimenez, F. Martinez, M.A. Rodrigo, and C. Saez, The $\mathrm{pH}$ as a key parameter in the choice between coagulation and electrocoagulation for the treatment of wastewaters. Journal of Hazardous Materials, 2009. 163(1): p. 158-164.

93. Singer, P.C., Control of disinfection by-products in drinking water. Journal of Environmental Engineering-ASCE, 1994. 120(4): p. 727-744.

94. Reckhow, D.A. and P.C. Singer, The removal of organic halide precursors by preozonation and alum coagulation. Journal American Water Works Association, 1984. 76(4): p. 151-157.

95. Sillanpaa, M., H. Sarkka, M. Vepsalainen, and M. Sillanpaa, NOM Removal by Electrochemical Methods. Natural Organic Matter in Water: Characterization and Treatment Methods. 2015. 81-111.

96. Chellam, S. and S.W. Krasner, Disinfection byproduct relationships and speciation in chlorinated nanofiltered waters. Environmental Science \& Technology, 2001. 35(19): p. 3988-3999.

97. Chellam, S., Effects of Nanofiltration on Trihalomethane and Haloacetic Acid Precursor Removal and Speciation in Waters Containing Low Concentrations of Bromide Ion. Environmental Science \& Technology, 2000. 34(9): p. 1813-1820.

98. Martinez-Huitle, C.A. and E. Brillas, Electrochemical alternatives for drinking water disinfection. Angewandte Chemie-International Edition, 2008. 47(11): p. 1998-2005.

99. Jeong, J., C. Kim, and J. Yoon, The effect of electrode material on the generation of oxidants and microbial inactivation in the electrochemical disinfection processes. Water Research, 2009. 43(4): p. 895-901.

100. Delaire, C., C.M. van Genuchten, K.L. Nelson, S.E. Amrose, and A.J. Gadgil, Escherichia coli Attenuation by Fe Electrocoagulation in Synthetic Bengal Groundwater: Effect of $\mathrm{pH}$ and Natural Organic Matter. Environmental Science \& Technology, 2015. 49(16): p. 9945-9953.

101. Ghernaout, D., A. Badis, A. Kellil, and B. Ghernaout, Application of electrocoagulation in Escherichia coli culture and two surface waters. Desalination, 2008. 219(1-3): p. 118-125.

102. Ghernaout, D., M.W. Naceur, and A. Aouabed, On the dependence of chlorine by-products generated species formation of the electrode material and applied charge during electrochemical water treatment. Desalination, 2011. 270(1-3): p. 9-22.

103. Noubactep, C., A. Schoner, and P. Woafo, Metallic Iron Filters for Universal Access to Safe Drinking Water. Clean-Soil Air Water, 2009. 37(12): p. 930-937. 
104. Jacangelo, J.G., J.M. Laine, K.E. Carns, E.W. Cummings, and J. Mallevialle, Low-pressure membrane filtration for removing giardia and microbial indicators. Journal American Water Works Association, 1991. 83(9): p. 97106.

105. Zhu, B., D.A. Clifford, and S. Chellam, Comparison of electrocoagulation and chemical coagulation pretreatment for enhanced virus removal using microfiltration membranes. Water Research, 2005. 39(13): $p$. 3098-3108.

106. Noubactep, C., On the mechanism of microbe inactivation by metallic iron. Journal of Hazardous Materials, 2011. 198(0): p. 383-386.

107. Kim, J.Y., C. Lee, D.C. Love, D.L. Sedlak, J. Yoon, and K.L. Nelson, Inactivation of MS2 Coliphage by Ferrous Ion and Zero-Valent Iron Nanoparticles. Environmental Science \& Technology, 2011. 45(16): p. 6978-6984.

108. Matsushita, T., N. Shirasaki, Y. Matsui, and K. Ohno, Virus inactivation during coagulation with aluminum coagulants. Chemosphere, 2011. 85(4): p. 571-576.

109. Kreißel, K., M. Bosl, M. Hugler, P. Lipp, M. Franzreb, and B. Hambsch, Inactivation of F-specific bacteriophages during flocculation with polyaluminum chloride - A mechanistic study. Water Research, 2014. 51: p. 144-151.

110. Gutierrez, L. and T.H. Nguyen, Interactions between Rotavirus and Suwannee River Organic Matter: Aggregation, Deposition, and Adhesion Force Measurement. Environmental Science \& Technology, 2012. 46(16): p. 8705-8713.

111. Matsushita, T., N. Shirasaki, Y. Tatsuki, and Y. Matsui, Investigating norovirus removal by microfiltration, ultrafiltration, and precoagulation-microfiltration processes using recombinant norovirus virus-like particles and real-time immuno-PCR. Water Research, 2013. 47(15): p. 5819-5827.

112. Shirasaki, N., T. Matsushita, Y. Matsui, M. Kobuke, and K. Ohno, Feasibility of in-line coagulation as a pretreatment for ceramic microfiltration to remove viruses. Journal of Water Supply Research and Technology-Aqua, 2010. 59(8): p. 501-511.

113. Chellam, S., M.R. Wiesner, and C. Dawson, Slip at a uniformly porous boundary: Effect on fluid flow and mass transfer. Journal of Engineering Mathematics, 1992. 26(4): p. 481-492.

114. Shirasaki, N., T. Matsushita, Y. Matsui, and K. Ohno, Effects of reversible and irreversible membrane fouling on virus removal by a coagulation-microfiltration system. Journal of Water Supply Research and TechnologyAqua, 2008. 57(7): p. 501-506.

115. Cañizares, P., F. Martínez, C. Jiménez, J. Lobato, and M.A. Rodrigo, Coagulation and Electrocoagulation of Wastes Polluted with Dyes. Environmental Science \& Technology, 2006. 40(20): p. 6418-6424.

116. Holt, P.K., G.W. Barton, and C.A. Mitchell, The future for electrocoagulation as a localised water treatment technology. Chemosphere, 2005. 59(3): p. 355-367.

117. Lakshmanan, D., A Systematic Study of Arsenic Removal from Drinking Water Using Coagulation-Filtration and Electrocoagulation-Filtration., in Civil and Environmental Engineering. 2007, University of Houston: Houston, TX.

118. van Genuchten, C.M., A.J. Gadgil, and J. Pena, Fe(III) Nucleation in the Presence of Bivalent Cations and Oxyanions Leads to Subnanoscale 7 angstrom Polymers. Environmental Science \& Technology, 2014. 48(20): p. $11828-11836$.

119. van Genuchten, C.M., J. Pena, S.E. Amrose, and A.J. Gadgil, Structure of Fe(III) precipitates generated by the electrolytic dissolution of $\mathrm{Fe}(\mathrm{O})$ in the presence of groundwater ions. Geochimica et Cosmochimica Acta, 2014. 127: p. 285-304. 
Graphical Abstract

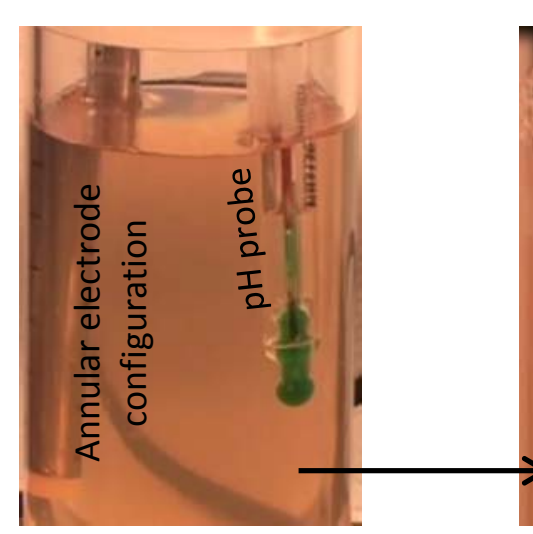

NOM containing turbid surface water prior to electrolysis
Electrolysis generates aluminum, which undergoes hydrolysis before coagulation. Simultaneous release of hydrogen bubbles can also be seen.

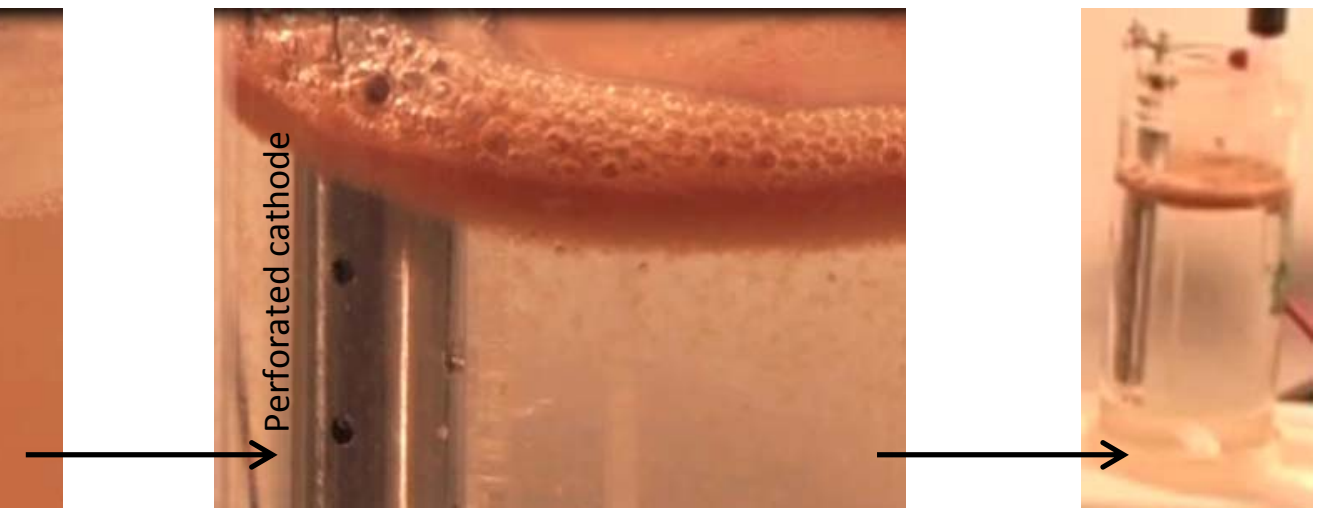

Flocs formed by electrocoagulation can be seen in the water column. Concurrent electroflotation induced by hydrogen gas is also visible.
Treated surface water. Decrease in NOM and turbidity can be visualized by the higher clarity of the water in the electrolysis cell. Electrofloating layer is clearly seen. 